\title{
Glossoscolecidae (Oligochaeta) do \\ Instituto Nacional de Pesquisas da Amazônia
}

\author{
Gilberto Righi (*) \\ lone Ayres $(" \#)$ \\ Elizabeth C. R. Bittencourt (")
}

\begin{abstract}
Resumo
Estudadas 13 espécies de Oligochaeta, Glossoscolecidae, da Amazônia brasileira. Dois gêneros novos são elegidos, Tuiba, gen. n. com duas espécies, T. dianae, sp. n. e T. tipema, sp. n. e Amazo, gen. n. com uma espécie, A. nia, sp. n. As seguintes es. pécies e subespécies novas são descritas: Andiorrhinus venezuelanus tarumanis, subsp, n., A. caudatus, sp. n., Rhinodrilus brasiliensis buritis, subsp. n., R. lucilleae, sp. n., R. curiosus, sp. n., R. elisianae, sp. n. e Glossodrilus (G.) sucunduris, sp. L. Andiorrhinus amazonius Michaelsen, 1918 é redescrito. Novas ocorrências são indicadas para Andiodrilus icomi Righi, 1971 e Pontoscolex core thrurus (Fr. Müller, 1857). E apresentada uma chave para as espécies de Rhinodrilus com dois pares de espermatecas.
\end{abstract}

\section{INTRODUÇÃo}

A fauna oligoquetológica da Região Amazônica tem atraído a atenção de eminentes pesquisadores como Cognetti de Martiis, Michael. sen e Cernosvitov. Não obstante, ela representa ainda uma grande lacuna em nossos conhecimentos. A enorme atividade humana na Amazônia durante a última década, com sucessivas alterações do meio, torna imprescindivel o seu melhor conhecimento. Foi assim, com grande satisfação, que vimos a possibilidade de estudar esta coleção.

Teoricamente, quando da descrição de uma espécie nova, um espécimem bem representativo deve ser o holótipo. Contudo, a classificação dos Oligochaeta, já ao nível de familia, baseia-se fundamentalmente em caracteres internos. Uma dissecação, por mais cuidadosa que seja, destroi numerosos caracteres de importância sistemática. Para as Glossoscoleci- dae complica-se mais pela necessidade de cortes ao micrótomo a fim de se estudar; entre outras, as estruturas das glândulas calcifèras e do aparelho genital. Não podemos designar como holótipo um animal íntegro, porque não conhecemos sua organização e, também, não podemos designar um dos restos altamente incompletos. Todas as observações que se seguem foram baseadas em animais fixados em formalina $10 \%$ e em cortes seriados corados pela Hematoxilina de Ehrlich - Eosina. Síntipos encontram-se depositados no Instituto $\mathrm{Na}$ cional de Pesquisas da Amazônia (Manaus).

Tuiba, gen. $\mathrm{n}$.

DIAGNOSE

Cerdas dispostas em oito linhas longitudinais regulares. Dois pares de poros masculincs intraclitelares. Uma moela em VI. Três pares de glândulas calcíferas em VII - IX, do tipo saco parcionado (Fachkapseltaschen) na região mediana e tubular simples (Schlauchtaschen) no ápice. Holândrico e metagínico. Câmaras copulatórias ausentes. Espermatecas presentes.

Tipo do gênero: Tuiba dianae, sp. n.

CONSIDERAÇõ̃ES

Pela estrutura das glândulas calcíferas e organização da parte terminal do aparelho re produtor masculino, Tuiba distingue-se dos demais gêneros das Glossoscolecidae. Glândulas calcíferas estruturadas como sacos parcionados, "Fachkapseltaschen" de Michaelsen

(") - Departamento de Zoologia, Universidade de São Paulo, São Paulo

(") - Instituto Nacional de Pesquisas da Amazônia, Manaus. 
(1918: 49, 85) são conhecidas nos segmento: VII - XIV do gênero monotípico quimbalá Michaelsen, 1935, do qual se desconhece o número e posição dos poros masculinos. Glandulas calciferas nos segmentos VII - IX, com estrutura lamelar passando a tubular no ápicc ocorrem em Andiorrhinus paraguayensis holm. greni Michaclsen, 1918, A. amazonius Michaelsen, 1918 e A. pictus Michaelsen, 1926. que podem representar formas de transição entre a estrutura apresentada por Tuiba e a tipicamente lamelar (Lamellentasche) de Andiorrhinus (Michaelsen, 1918: 51, pl. 2, figs. 23, 24). De $A$. paraguayensis holmgreni e $A$. pictus desconhecem-se os poros masculinos, que säo em número de um par em $A$. amazonius. As espermatecas das duas últimas espécies tem crganização complexa como as $T$. dianae. Eudevoscolex vogelsangi Cordero, 1944, única espécie c'o cênero, possui dois pares de poros masculinos, porém difere de Tuiba por apresentar câmaras copulatórias associadas aos poros musculinos e glândulas calcíferas tipicamente lamelares (Cordero, 1944b: 2).

Tuiba dianae, sp. $n$. (Figs. 1.6)

\section{MATERIAL}

BRASIL, Amazonas: ilha de Camanaú, em solo com palmeires, 1 exemplar clitelado e 1 maduro sclitelado, ambos sem a extremidade posterior (INPAZ-15), D. Magor col. 3/10/1947. Estrada

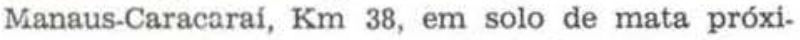
mo a igarapé, 1 exemplar clitelado e. 2 maduros aclitelados, todos sem a extremidade posterior (INPAZ-44), I. Ayres col. 9/1/1975.

O maior animal clitelado tem $90 \mathrm{~mm}$ de comprimento e 76 segmentos. O diâmetro anterior é de $3 \mathrm{~mm}$, no clitelo $5 \mathrm{~mm}$ e na regiâo mediana do corpo $3,5 \mathrm{~mm}$. Em todos os exemplares os dois primeiros segmentos são rudimentares. O segmento I é invaginável e do parede membranosa; o II tem um sulco longitudinal de cada lado, na linha dos nefridióporos. A cor do dorso é violeta escura, seme. Ihante à do $n .^{\circ} 674$ de Séguy (1936), clareando em direção à linha dos nefridióporos; o ventre é azul violáčeo, como o $\mathrm{n}^{\circ}{ }^{\circ} 575$. O prostômio é tentaculiforme e tão longo quanto os dois primeiros segmentos.
O clitelo é em forma de sela nos segmentos $X V I-X X V(=10)$. Papilas pubertais, com a forma de uma área circular escura, envolvem as cerdas ventrais de XVI - XXIV; as papilas são ligeiramente proeminentes em XVI -. XVIII. Um par de traves pubertais estende-so de $2 / 3$ XIX $-1 / 2$ XXIII, pouco para fora de $b$. As traves são ligeiramente deprimidas, de: cor cinza escura e circundadas por uma margem branca pouco espessa. As células glan. dulares das traves salientam-se na cavidade do corpo como duas séries volumosas, interrompidas nos intersegmentos. Outra estrutura sexual acessória é o espessamento da face ventral de $1 / 2 \mathrm{VI}-1 / 2 \mathrm{IX}$, no espaço $c c$. Exceto o clitelo, as demais estruturas sexuais já estão diferenciadas nos exemplares aclitelados. Os poros masculinos são microscópicos e reconheciveis apenas em cortes; em número de dois pares, abrem-se no interior das traves pubertais, no terço anterior de XIX e XX, próximo aos intersegmentos $19 / 20$ e 20/21. O par de poros femininos, também microscópicos, situam-se no terço posterior de XVII, em série com as cerdas ventrais. Três pares de poros de espermatecas encontram-se nos intersegmentos $6 / 7-8 / 9$, em série com as cerclas laterais.

As cerdas têm distribuiçăo lumbricina regular, iniciando-se as séries ventrais em IV e as laterais em VII. As cerdas normais são sigmóides, alongadas, com um nódulo subme diano e o $1 / 5$ apical ornamentado por 4 séries alternas de $2-4$ cicatrizes semilunares. As cerdas ventrais são ligeiramente malores do que as laterais. Na região mediana do corpo, as cerdas ventrais atingem em média $621 \mu \mathrm{m}$ de comprimento e as laterais $509 \mu \mathrm{m}$. No segmento $\mathrm{XL}, a a: a b: b c: c d: d d=5,66: 1,00: 9,66:$ $0,50: 28,66$. As cerdas ventrais de XVI - XXIV e as laterais de VI - VIII são transformadas em genitais. Os $2 / 3$ apicais destas cerdas é ornamentado por 4 séries de cicatrizes abertas para o ápice e dispostas alternadamente. O número de cicatrizes por série varia de $20-$ 23. Nos segmentos clitelares, as cerdas genitais são arqueadas, especialmente as $b$ de XVIII (Fig. 1); raramente têm a porção ornamentada reta, como ocorre nos segmentos VI - VIII. Em XVI - XXIV, o comprimento das cerdas genitais varia de $1,012-2,037 \mathrm{~mm}$. 
em média $1.426 \mathrm{~mm}$, sendo as maiores as $b$ de XVIII. Em VI - VIII o comprimento das cerdas genitais varia de $1,037-1,812 \mathrm{~mm}$, em média $1,406 \mathrm{~mm}$, sendo as maiores as $c$ e $d$ de VIII. Tufos glandulares volumosos e salientes na cavidade do corpo, abrem-se nos folículos das cerdas genitais, próximo à superfície. Nos segmentos clitelares estes folículos têm igual desenvolvimento, e nos segmentos anteriores são maiores em VII.

Os septos anteriores são extremamente frágeis, com a forma de longos cones interpenetrados e só reconhecíveis em cortes. O primeiro septo visível em dissecação é o 12/13. Os $12 / 13-16 / 17$ são ligeiramente cônicos e pouco mais espessos do que os demais, que são frágeis e transversais. A faringe cilíndrica estende-se até a altura do segmento VII externo. Segue-se o esôfago anterior que forma um papo cônico, com a porção alargada posterior abrindo-se em uma moela musculosa e com a forma de vaso de gargalo curto. A moela situase em VI, porém devido ao seu tamanho e forma dos septos, corresponde externamente aos segmentos $X-X I I$. Três pares de glândulas calciferas grandes e piriformes abrem-se ventro-lateralmente no esôfago em VII - IX. As glândulas dispōem-se acompanhando os septos, de modo que seu fundo cego esta voltado para diante, e as de VIII são recobertas parcialmente pelas de VII e IX. Em cada glândula, próximo à abertura, há lamelas de alturas diferentes, mais numerosas na face ventral e a maioria tem bordo livre (Fig. 3). Um volumoso vaso proveniente do plexo esofágico pene. tra através da parede lateral da glândula, pouco após sua abertura e corre longitudinalmente na na sua porção central, como um eixo onde se prendem a maioria das lamelas (Fig. 4). Na região mais ental da plândula, o vaso subdivide-se e as lamelas, fracamente ramificadas, prendem-se irregularmente entre si, resultando tubos largos e curtos (Fig. 5). A superfície das lamelas, especialmente próximo a abertura das giândulas, é recoberta por cílios. O esôfago posterior, bastante delgado e sem outro tipo de estrutura calcífera, continua uniforme até o segmento XXIII, onde se situa a transição esôfago:Intestino. $O$ intestino começa a dilatar-se em XXIV e em XXV já atinge o diâmetro que segue posteriormente. Cecos intestinais fal- tam. O tiflosole, iniciado em XXIV, já tem em XXVI a forma definitiva de uma lâmina alta ? com a margem livre dobrada em canaleta.

h.á um par de holonefrídios por segmento. abrindo-se através de um pequeno esfincter em série com as cerdas laterais. Os nefrídios de $\mathrm{VI}$ e anteriores têm as alças dispostas em um enovelado de cada lado do esôfago anterior e papo. O aparelho circulatório consta de 3 troncos longitudinais principais, os vasos dorsal, ventral e subneural. O vaso dorsal é retilíneo ao longo de toda a extensão. Apresente. se mais dilatado em XXIV; para diante sofre fortes constriçōes inter-segmentares, resultando num conjunto de nódulos, que se tornam sucessivamente menores até o segmento VII e termina por uma bifurcaçāo na face posterior da moela, em VI. Três pares de delgados corações laterais encontram-se em VII - IX. O vaso supra-esofágico é reconhecivel ao longo de todo o esôfago posterior, apresentando.s? mais dilatado em $\mathrm{X}$ e XI, onde dois pares de volumosos corações intestinais comunicam-no com o vaso ventral. Outros dois pares de corações intestinais encontram-se em XII e Xill. ( par de vasos extra-esofágicos inicia-se no eno. velado nefridial de cada lado do esôfago anterior. Corre para trás como dois vasos volume. sos laterais à moela, fundindo-se a seguir em um vaso único aderido à face ventral do esôfa. go posterior.

Dois pares de sacos testiculares volumosos situam-se na cavidade dos segmentos $X$ e XI. Os sacos simétricos fundem-se ventralmente entre si e estão intimamente unidos os dos dois segmentos, de maneira que sua separação só é possível em cortes. Devido à forma cônica dos septos, os sacos testiculares dcsenvolvem-se para a frente e para cima, resultando no conjunto a forma de uma sela aberta dorsalmente, que envolve o esôfago e as glândulas calcíferas. Os corações e nefrídios de $X$ situam-se no interior dos sacos testiculares: os de XI apenas parcialmente. Vesículas seminais faltam. Os dois canais deferentes de cada lado correm acima da musculatura longitudinal. próximo à linha de cerdas ventrais, até o segmento XIX A seguir, continuam no interior da musculatura longitudinal, abrindo-se, os do primeiro par de testículos, na região posterior de $\mathrm{XIX}$ e, os do segundo par, na região posterior 
de XX. Os ovários têm a forma de duas lâminas largas, onduladas e fracamente recortacias dispostas ventralmente em XIII, mas devido à forma dos septos, encontram-se na aitura do segmento XVI externo. Assim, os ovidutos, embora curtos, abrem-se na região posterior de XVII. Três pares de espermatecas situam. se em VII - IX (Fif. 2, S), recobertas parcialmente pelas glândulas (G) que se abrem nos folículos setigeros. As espermatecas tornamse maiores no sentido antero-posterior $(1<2<3)$. Em cada espermateca (Fig. 6) os $2 / 3$ basais do duto são envolvidos por uma massa conjuntiva revestida por fraca capa muscular, onde se encontram numerosos divertículos, como dígitos de alturas diferentes, que se abrem na porção ectal do duto. Da massa conjuntivo-muscular, que pode ser arredondada ou ovóide, salienta-se o terço ental do duto e a ampola ovóide e achatada.

O nome da nova espécie foi dado em ho. menagem à Srta. Diana Magor, que coletou parte dos animais.

Tuiba tipema, $\mathrm{sp} . \mathrm{n}$. (Figs. $7-10$ )

MATERIAL

BRASIL, Amazonas: margem de igarapé, próximo à foz do rio Tarumã-mirim, 6 exemplares clitelados e 35 maduros aclitelados (INPAZ-30), G. Righi, H. Schubart e E. Rufino col. 2/7/1975.

O comprimento dos animais clitelados varia de 90 a $110 \mathrm{~mm}$ e o diâmetro anterior de $2,0-2,5 \mathrm{~mm}$, no clitelo de $2,5-3,0 \mathrm{~mm}$ e na região mediana do corpo de $2,0-2,3 \mathrm{~mm}$. A região posterior é ligeiramente achatada dorso-ventralmente, suas maiores medidas variam de $1,2 \times 1,5 \mathrm{~mm}$ a $1,3 \times 1,9 \mathrm{~mm}$. O número de segmentos varia de $130-155$. Os dois primeiros segmentos são rudimentares, parcialmente invaginados e percorridos por uma reentrância profunda de cada lado, na linha dos nefridióporos; o conjunto lembra dois pares de lábios superpostos. A cor do dorso é marrom avermelhada, semelhante à do $n .^{\circ} 714$ de Séguy $(1936)^{\mathrm{N}} \mathrm{e}$ a do ventre é marrom clara como a do $n .^{\circ} 680$. O prostômio é em forma de tromba, com numerosos sulcos anelares e está parcial ou totalmente invaginado em uma bainha tubular acima da massa faríngea. O clitelo. pouco intumescido, é em forma de sela nos segmentos $X V I-X X V(=10)$; seu limite inferior situa-se pouco acima de $b$ e a cor é violeta, como a do n. 26 de Séguy (1936). Um sulco longitudinal e pouco profundo situa-se lateralmente às cerdas $b$ do terço posterior de $X I X$ ao anterior de XXIII. A região ventral de XVIII - XXIII, no espaço bb é um pouco aprofundada, podendo, em alguns animais, apresentar sulcos longitudinais mal definidos. Papilas giandulares pequenas e esbranquiçadas circundam as cerdas ventrais de XV e de XVIII XXIII, cuja área fica ligeiramente intumescida.

As cerdas dispõem-se em 8 séries longitudinais regulares, iniciando-se as ventrais em IV e as laterais em VI. As cerdas normais são sigmóides, alongadas, com pequeno espessamento submediano, e o $1 / 7$ apical é ornamentado por 4 séries de cicatrizes semilunares. abertas para o ápice. O número de cicatrizes por série varia de $2-3$. O comprimento das cerdas ventrais é ligeiramente maior do que o dás laterais e mais ou menos uniforme ao lon. go do corpo. O comprimento das cerdas ventrais varia de $213,14-268,39 \mu \mathrm{m}$, em média $239,58 \mu \mathrm{m}$ e das dorsais varia de $181,56-205,24$ $\mu \mathrm{m}$, em média $193,80 \mu \mathrm{m}$. As relações entre as cerdas nas regiões mediana e posterior do corpo encontram-se na Tabela 1. As cerdas $c$ e $d$ de VI - VIII e as $a$ e $b$ de XV - XXIII são transformadas em genitais. As de $\mathrm{VI}-\mathrm{VIII}$ estão deslocadas do equador para a região posterior dos segmentos, emergindo pouco anteriormente aos poros das espermatecas em 6/7 $8 / 9$. Estas cerdas são mais ou menos retas e seu comprimento varia de $0,502-1,737 \mathrm{~mm}$, em média $0,865 \mathrm{~mm}$; geralmente as de VI são maiores. As de XV - XXIII são, ora mais ora menos, arqueadas e o comprimento varia de C,568 - 2,162 $\mathrm{mm}$, em média $1,233 \mathrm{~mm}$, sendo as de XV geralmente mais longas. Os $2 / 3$ ou $3 / 4$ apicais das cerdas de ambas as regiōes são ornamentados por 4 séries de cicatrizes que se dispõem segundo dois padrōes: 1) as 4 séries de cicatrizes alternam-se entre si ao longo do eixo da cerda (Fig. 7); 2) as cicatrizes são opostas duas a duas em alturas diferentes num giro de $180^{\circ}$ (Fig. 8). No segundo caso, duas séries opostas são mais profundas, re- 


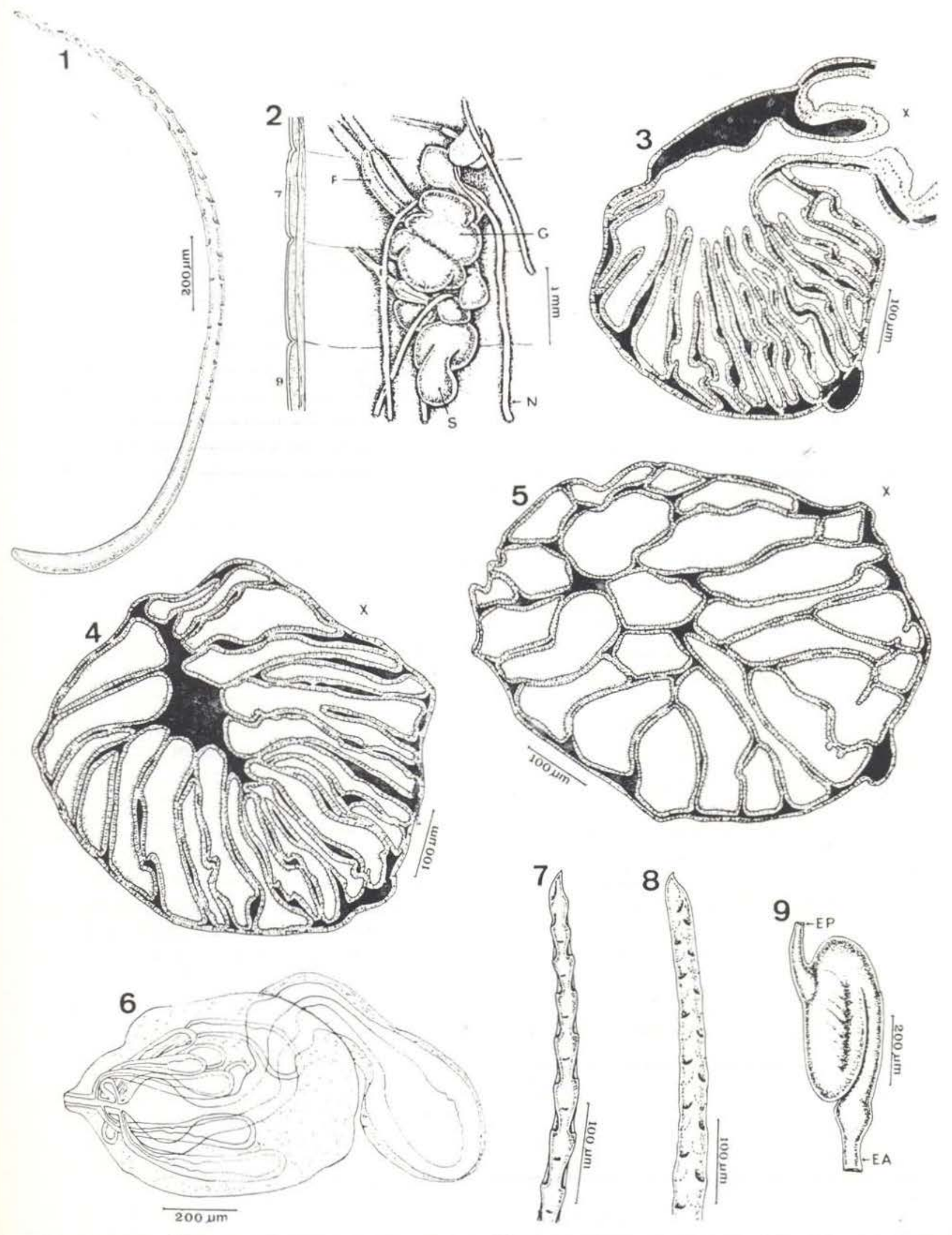

ESTAMPA I - Tuiba dianae, gen. n., sp. n.: 1 - cerda zenital do segmento XVIII; 2 - regiăo das esperrnatecas; $3-5$ - cortes transversais ectal, mediano e ental da glândula calcifera esquerda de IX; 6 - espermatẹca de VIII. Tuiba tipema, sp. n.; 7 - ápice de cerda genital de XVIII; 8 - ápice đe cerda genital de XXI; 9 - moela vista de perfil. ( $\mathrm{EA}=$ esôfago anterior; $\mathrm{EP}=$ esôfago posterior; $\mathrm{F}=$ folículo de cerca; $\mathrm{G}=$ tufo glandular; $\mathrm{N}=$ nefrídio; $\mathrm{S}=$ espermateca; $\mathrm{X}=$ posição do esôfago). 
sultando uma série longitudinal de nós e entre nós. A extremidade apical das cerdas genitais termina em ponta fina e curvada em direção à margem convexa da cerda.

Associados ao grande desenvolvimento da moela e da parte anterior do trato digestivo, os septos anteriores são cônicos e interpenetrados até o 18/19. O primeiro septo visível dorsalmente é o 12/13. Anteriormente os septos são perceptíveis apenas em cortes microscópicos e só ventralmente ao tubo digestivo. faltam dorsalmente. Nos cortes vê-se que os septos, a partir de $12 / 13$, prendem-se dorsalmente num intersegmento e ventralmente no intersegmento anterior ou mais para a frente. A disposição regular dos septos só ocorre a partir do $22 / 23$ ou $23 / 24$.

A massa faríngea prolonga-se até a altura do segmento $V$ externo. O esôfago anterior dilata-se em um pequeno papo, que se abre ventralmente na moela. Esta é grande, ovóide e fortemente muscular; situa-se no segmento VI porém, dado o seu volume e forma dos septos, ocupa o espaço correspondente aos segmentos IX - XIII externos. O esôfago posterior parte da região póstero-dorsal da moela (Fig. 9). Três pares de glândulas calcíferas situam-se em VII - IX. As glânaulas têm a forma de um tubo curvo em S (Fig. 10) e dlspõem-se de modo que as de VIII são, em geral, recobertas pelas de VII e IX. O duto de cada glândula corre transversalmente sob o esôfago. une-se com o simétrico e abrem-se por uma abertura comum, na linha média ventral do esô. fago. A estrutura das glândulas calcíferas é semelhante à encontrada em Tuiba dianoe. O esôfago posterior continua uniforme até XXIV, onde faz transição com o intestino, que se inicia em XXV. Neste segmento surge o tifloso le, que é uma lâmina larga e dobrada em S. Cecos intestinais faltam.

Do aparelho circulatório ressaltam 4 pares de corações intestinais volumosos em X XIII. Três pares de coraçōes laterais situamse em VII - IX. O vaso subneural é delgado e localiza-se no bordo superior de uma massa conjuntiva ricamente vascularizada e com a forma de uma canaleta, em cuja reentrância situa-se a cadeia nervosa. Em cada segmento há um par de holonefrídios abrindo-se através de um esfincter musculoso. Os nefridióporos são perceptiveis a partir de $4 / 5$, em série com $c d$ na região pré-clitelar e com $c$ na post-clitelar.

Dois pares de sacos testiculares situam-se em $\mathrm{X}$ e $\mathrm{XI}$. Os sacos simétricos fundem-se ventralmente entre si e desenvolvem-se láterodorsalmente, envolvendo a maior porção dos corações intestinais e dos nefrídios desses segmentos. Dois pares de vesículas seminais largas e curvas recobrem como valvas os corações de XI e XII. O primeiro par de vesículas situa-se no interior do segundo par de sacos testiculares. Os dois canais deferentes de cada lado correm mais ou menos paralelos na cavidade do corpo até o segmento XIX. A seguir penetram na musculatura parietal, abrindose o primeiro par em 19/20 e o segundo em $20 / 21$, poucc para fora da linha de cerdas $b$. Um par de ovários prende-se à face posterior

TABELA 1 - Tuiba tipema, sp. n., relações entre as cerdas de 5 exemplares clitelados.

\begin{tabular}{|c|c|c|c|c|c|c|c|c|c|c|c|c|c|c|c|c|c|}
\hline \multirow{2}{*}{ Exemplar } & \multicolumn{8}{|c|}{ Segmentos XL - L } & \multicolumn{9}{|c|}{ Segmentos CX - CXX } \\
\hline & aa & : & $\mathbf{a b}$ & : & be & : & ed & : dd & aa & : & $\mathbf{a b}$ & : & be & : & cd & : & dd \\
\hline A & 6,44 & : & 1,00 & : & 9,59 & : & 0,45 & : 23,46 & 7,74 & : & 1,00 & : & 11,46 & : & 0,69 & : & 30,93 \\
\hline B & 10,50 & : & 1,00 & : & 16,50 & : & 0,62 & : 38,75 & 6,89 & : & 1,00 & : & 10,00 & : & 0,67 & : & 22,89 \\
\hline C & 8,94 & : & 1,00 & : & 9,55 & : & 0,52 & : 24,73 & 7,50 & : & 1,00 & : & 8,76 & : & 0,87 & : & 26,58 \\
\hline D & 7,20 & : & 1,00 & : & 12,56 & : & 0,60 & : 32,25 & 8,20 & : & 1,00 & : & 12,75 & : & 0,82 & : & 32,25 \\
\hline $\mathbf{E}$ & 6,40 & : & 1,00 & : & 9,80 & : & 0,50 & : 27,85 & 6,20 & : & 1,00 & : & 10,80 & : & 0,60 & : & 27,60 \\
\hline Média & 7,89 & : & 1,00 & : & 11,60 & : & 0,54 & : $\quad 29,41$ & 7,30 & : & 1,00 & : & 10,75 & : & 0,73 & : & 28,05 \\
\hline
\end{tabular}


de $12 / 13$, mas devido à forma dos septos, localiza-se bem mais para trás, de modo que os cvidutos, embora curtos, abrem-se na região posterior de XVII, próximo a $17 / 18$, pouco lateralmente às cerdas $b$. Três pares de espermatecas abrem-se em $6 / 7-8 / 9$, em série com as cerdas laterais. As espermatecas tornam-se maiores no sentido antero-posterior i $<2<3)$ e sua organização é semelhante à cie Tuiba dianae. Em cada espermateca, vários aiverticulos partem quase da mesma altura, da porção ectal do duto. Os divertículos são tubulares, em geral dicotômicos, e cada ramo termina em pequena dilatação. Os divertículos e os $2 / 3$ ectais do duto são envolvidos por uma massa conjuntiva. Desta massa projetase a porção terminal do duto, que se abre em uma ampola ovóide e achatada. Espermatozóides preenchem os divertículos e faltam na am. pola, que aparece vazia.

\section{LONSIDERAÇÕES}

Tuiba tipema aproxima-se bastante de $T$. dianae, distinguindo-se pela forma típica da moela, falta de traves pubertais associadas a rico campo glandular interno e falta de glândulas volumosas associadas às cerdas genitais das espermatecas.

O nome da nova espécie deriva da lingua Tupi, significando "focinho afilado".

Andiorrhinus amazonius Michaelsen, 1918. (Figs. 11-17)

Andiorrhinus amazonius Michaelsen, 1918: 206, pl. 2, fig. 22 ,

\section{MATERIAL}

BRASIL, Amazonas: Estrada Manaus-Caracarai ramal do rio Cuieiras, 1 exemplar maduro aclitelado e 2 jovens (INPAZ-20), E. F. Nascimento col.

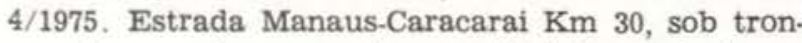
cos, 3 exemplares maduros aclitelados e 1 jovem (1NPAZ-26), I. Ayres col. 27/8/1974; Km 60 (Reserva Biológica da Campina), 5 exemplares clitelados. 18 maduros aclitelados e 34 jovens (INPAZ-21), I. Ayres col. 4/1975; 4 exemplares clitelados e 22 jovens (INPAZ-56), I. Ayres col. 12/5/1975. Estrada Manaus-Itacoatiara Km 26 (Reserva Ducke), no solo próximo ao igarapé do Barro Branco, 3 exemplares clitelados e 3 maduros aclitelados (INPAZ-37); no interior de troncos em decompo- sição, 7 exemplares clitelados e 17 maduros aclitelados (INPAZ-42), L. Antony, E. Rufino, E. M. Froehlich e G. Righi col. 23/6/1975.

A espécie era conhecida apenas pela descrição original, baseada em dois animais provenientes de Manaus. A redescrição seguinte baseia-se apenas em nossos exemplares.

O comprimento dos animais clitelados varia de $70-85 \mathrm{~mm}$. O diâmetro na região anierior varia de $2,38-2,57 \mathrm{~mm}$, no clitelo de $3,04-3,14 \mathrm{~mm}$, na regiăo mediana do corpc de $2,09-2,38 \mathrm{~mm}$ e na região posterior de $1,33-1,71 \mathrm{~mm}$. O número de segmentos varia de $140-170$. Os dois primeiros segmentos são rudimentares, parcial ou totalmente invaginados e percorridos por um sulco longitudinal na linha dos nefridióporos. Os demais segmentos têm a superfície lisa. A cor dos animais recem-fixados é laranja clara, semelhante à do $n .^{\circ} 190$ de Séguy (1936), mais nítida no dorso dos segmentos pré-clitelares; o clitelo, quando pouco desenvolvido, é laranja escuro semelhante ao $n .^{\circ} 194$ e de cor branca leitosa quando intumescido. Nos animais fixados há mais tempo estas tonalidades desaparecem e os animais tomam cor cinza clara ou escura, devida ao conteúdo intestinal. O prostômio é tentaculiforme, com numerosos sulcos anelares. Quando distendido é tăo longo quanto o terceiro e mais a metade do quarto segmento. O prostômio retrai-se no interior de uma bainha situada acima da massa faríngea e do gânglio cerebróide. A bainha atinge até a altura do segmento VI externo e continua. se por um musculo retrator que se prende na parede do corpo junto ao intersegmento $7 / 8$. A cavidade da bainha é revestida por células giandulares, principalmente nas faces laterais e ventral.

As cerdas dispōem-se em 8 séries longitudinais regulares a partir do segmento III $-\mathrm{V}$. As relações entre as cerdas em 4 exemplares encontra-se na Tabela 2. As cerdas normais são sigmóides e com um espessamento media. no: seu terço apical é curvo em gancho. No lado côncavo da porção apical ocorrem freद̧üentemente 2 séries alternas de 2 cicatrizes semilunares pouco demarcadas. As cerdas ventrais são ligeiramente maiores do que as laterais. Na regiäo mediana do corpo, o com- 
primento das cerdas ventrais varia de 306 -$431 \mu \mathrm{m}$, em média $361 \mu \mathrm{m}$ e das laterais de 193 $-250 \mu \mathrm{m}$, em média $214 \mu \mathrm{m}$. As cerdas $b$ de XII - IX e de XX - XXII - são transformadas em genitais e deslocadas para a linha de $a$; as demais cerdas destes segmentos são equatoriais. Em VII - iX, as cerdas $b$ emergem da região anterior dos segmentos, associadas às invaginaçōes onde se abrem os poros das espermate. cas (Fig. 11). Em XX - XXII as cerdas $b$ emergem da região posterior dos segmentos, associadas às invaginaçōes dos intersegmentos 20/ $21-22 / 23$. As cerdas genitais são de 2 tipos. As de VII - IX eXXII são retilíneas e seus $2 / 3$ apicais ornamentados por 4 séries alternas de cicatrizes semilunares, alongadas e abertas pa. ra o ápice (Fig. 12). Em VII - IX o comprimento das cerdas varia de $675-762 \mu \mathrm{m}$. em média $716 \mu \mathrm{m}$ e o número de cicatrizes por série oscila entre $11-14$, em média 11 . As de XXIl medem de $1,131-1,212 \mathrm{~mm}$, em média $1,170 \mathrm{~mm}$ de comprimento e o número de cicatrizes por é de $11-13$, em média 12. As cerdas de $X X$ e XXI tem o quinto apical dobrado em ângulo de aproximadamente $150^{\circ}$. Seus $2 / 3$ externos såo ornamentados, no lado convexo, por 2 sé. ries de cicatrizes alternas, especialmente pronunciadas na região de dobramento; em cada série ocorrem de 10 a 12 cicatrizes (Fig. 13).

$O$ clitelo é em forma de sela nos segmentos $X V I I-X X V \quad(=9)$. Seu limite inferior situa-se ao lado da série de cerdas $b$ (Fig. 14). A face ventral dos segmentos $X X-X X I I$ e espessada e, em dois exemplares, também a de $X V I I$. Um par de sulcos longitudinais situa-se em XXI - XXII, em série com $b$. Na face ven- tral, os sulcos intersegmentares $20 / 21$ e $22 / 23$ são aprofundados e continuam-se na cavidade do corpo por 3 pares de invaginações saculiformes dispostas em série com a. Estas invaginações são fortemente musculares e na sua porção ental abrem-se células glandulares arranjadas em numerosos tufos piriformes. Estes caracteres sexuais secundários diferenciam-se antes do clitelo durante o processo de maturação. Os poros genitais são microscópicos. O par de poros masculinos abrem-se no equador de XXI, no interior dos sulcos longitudinais. O par de poros femininos situase na região posterior de XVIII, em série com as cerdas $b$. Três pares de poros de espermatecas encontram-se no interior de largas reentrâncias, nos intersegmentos $6 / 7-8 / 9$, em série com $a b$. Em cerca de $50 \%$ dos exemplares há um par de papilas pubertais brancas e proeminentes no equador, ou no terço anterior ou posterior do segmento IX, pouco para fora da linha de cerdas $b$. Papilas semelhantes podem ocorrer em VII, VIII e X.

$O$ primeiro septo visível em dissecção é o $6 / 7$. Todos os septos são frágeis. Os anteriores têm a forma de cones interpenetrados. que se tornam sucessivamente mais curtos até o $14 / 15$, os demais são transversais. O septo $9 / 10$ prende-se dorsalmente no intersegmento 10/11 e ventralmente no $9 / 10$. Disposição semelhante tem os septos seguintes até o 14/15. prendendo-se dorsalmente num intersegmento e ventralmente no intersegmento imediatamente anterior. Os demais septos têm disposição regular. Devido a este arranjo dos septos, um animal dissecado dorsalmente aparenta nảo

TABELA 2 - Andiorrhinus amazonius Michaelsen, 1918, relaçōes entre as cerdas de 4 exemplares.

\begin{tabular}{|c|c|c|c|c|c|c|c|c|c|c|c|c|c|c|c|c|c|}
\hline \multirow{2}{*}{ Exemplar } & \multicolumn{8}{|c|}{ Segmentos LX - LXX } & \multicolumn{9}{|c|}{ Segmentos CXL - CL } \\
\hline & aa & : & $\mathbf{a b}$ & : & be & : & cd & dd & aa & : & $\mathbf{a b}$ & : & bc & : & cd & : & dd \\
\hline $\mathbf{A}$ & 4,40 & : & 1,00 & : & 4,60 & : & 0,40 & $: \quad 13.60$ & 2,53 & : & 1,00 & : & 3,86 & : & 0,60 & : & 11,60 \\
\hline B & 4,23 & : & 1,00 & : & 5,23 & : & 0,38 & : 16,15 & 3,23 & : & 1,00 & : & 4,92 & : & 0,61 & : & 12,15 \\
\hline c & 3,44 & : & 1,00 & : & 4,72 & : & 0,38 & $: 12,94$ & 3,69 & : & 1,00 & : & 4,30 & : & 1,00 & : & 12,30 \\
\hline $\mathrm{D}$ & 3,13 & : & 1,00 & : & 5,53 & : & 0,53 & $: 13,93$ & 2,46 & : & 1,00 & : & 4,00 & : & 0,76 & : & 11,30 \\
\hline Média & 3,80 & : & 1,00 & : & 5,02 & : & 0,42 & $: \quad 14,16$ & 2,98 & : & 1,00 & : & 4,27 & : & 0,74 & : & 11,84 \\
\hline
\end{tabular}


possuir o septo $9 / 10$ e os órgãos genitais e coraçōes intestinais estarem situados um segmento para trás do real.

A massa faríngea é cilindrica e estende-se até o segmento $\mathrm{V}$ ou VI externos. Segue-se o curto esôfago anterior, que se dilata em um volumoso papo. Este abre-se em uma moela musculosa, em forma de vaso, no segmento VI, mas que corresponde externamente aos segmentos $1 / 2 \mathrm{VIII}-1 / 2 \mathrm{X}$. O esôfago posterior é retilíneo e atinge até o segmento XXII. Em VII - IX encontram-se 3 pares de glândulas calcíferas aproximadamente do mesmo tamanho, que se abrem ventro-lateralmente no esô. fago e se dirigem ventralmente para diante. Cada glândula compõem-se de uma porção tubular proximal e de um apêndice curvo distal (Fig. 16). A estrutura da porção tubular é do tipo de saco lamelar (Lamellentasche). Numerosas lamelas longitudinais, altamente ciliadas, unem-se irregularmente entre si e com a parede da glândula. Na porção distal as lamelas ramificam-se e fundem-se irregularmente, resultando um conjunto de largas câmaras sem cílios, que compõem o apêndice (Fig. 15). Neslas câmaras, e por vezes na regiāo lameiar, encontra-se calcário sob a forma de pó fino. O intestino começa a dilatar-se em XXIII, atingindo o diâmetro regular em XXVI. O tiflosole apresenta-se como uma lâmina larga, em forma de $S$, a partir de XXIII.

O vaso dorsal único e retilíneo apresenta uma forte dilatação em XXIII e pode ser seguido até a moela. Três pares de corações laterais delgados unem o vaso dorsal com o ventral, anteriormente às glândulas calcíferas, em VII - IX. Quatro pares de corações intestinais unem o vaso supra-esofágico com o ventral em $x-$ Xili. O vaso subneural é delgado e algo sinuose. Em cada segmento há um par de holonefrídios. Os nefridióporos săo reconhecíveis a partir de $3 / 4$, em série com as cerdas laterais. Os nefridios anteriores até os de VI enovelam-se ao redor do esôfago anterior.

Dois pares de sacos testiculares situam-se em $\mathrm{X}$ e XI. fundindo-se ventralmente os simé. tricos. Cada saco testicular prolonga-se dorsalmente por um apêndice foliáceo, sendo maior o do primeiro par. Dois pares de vesí culas seminais encontram-se em XI e XII. Os dois canais deferentes de cada lado correm mais ou menos paralelos na cavidade do corpo até o segmento XVIII, onde formam um enovelado. Continuam lado a lado até o segmento XX, penetram na musculatura parietal e fundem-se entre si pouco antes da abertura. Um par de ovários ventrais em XIII tem a forma de uma lâmina larga, ondulada e de margem livre recortada. Três pares de espermatecas complexas situam-se nos segmentos VII - IX, abrindo-se na região anterior das invaginações dos intersegmentos $6 / 7-8 / 9$. Em cada espermateca (Fig. 17), o duto é ovóide e de parede grossa, onde se encontram algumas câmaras seminais. Da porção ectal do duto partem numerosos divertículos tubulares, dobrados irregularmente e cheios de espermatozóides. A ampola ovóide é $1,5-2$ vezes mais longa do que o duto. Sua parede é glan. dular e a cavidade cheia de espermatozóides distribuídos no interior de uma massa albuminóide. Na porção posterior e mediana das invaginaçōes parietais abrem-se numerosas células glandulares piriformes e alongadas, que estão eńtremeadas com tecido conjuntivo e algumas fibras musculares, resultando uma estrutura compacta, arredondada Esta estrutura, bem como o duto da espermateca e seus divertículos estão envolvidos por uma massa de tecido conjuntivo, sendo a ampola a única parte livre. Em alguns animais, a massa conjuntiva é quase tão longa quanto a espermateca, situando-se sua porção interna. livre, ao lado da ampola. No interior dessa massa conjuntiva ocorrem largos espaços tissulares, onde podem ser vistos amebócitos. Associados a cada folículo de cerda genital há dois tufos glandulares piriformes, salientes na cavidade do corpo.

Andiorrhinus venezuelanus tarumanis, subsp.n. (Figs. $18-21$ )

\section{MATERIAI}

BRASIL, Amazonas: Estrada Manaus-Caracarai, 1 exemplar clitelado (INPAZ-17), W. Junk col. 18/10/1974. Próximo de igarapé do rio Cuieiras, 1 exemplar maduro aclitelado e 6 jovens (INPAZ-29), I. Ayres col, 28/6/1975. Margem de igapó próximo ¿̀ fóz do rio Tarumã-mirim, 5 exemplares maduros aclitelados e 21 jovens (INPAZ-28), G. Righi, H. Schubart e E. Rufino col, 2/7/1975 
Todos os exemplares maduros estão frag. mentados, os segmentos posteriores faltam ou estão em regeneração. Na descrição abaixo, o animal da primeira procedência será designado por $\mathrm{A}$ e os demais por $\mathrm{B}$.

O exemplar A mede $185 \mathrm{~mm}$ de comprimento, excetuando-se uma porçāo de $6 \mathrm{~mm}$ em regeneração, que aparece como um pequeno apêndice terminal. O diâmetro anterior é de $8 \mathrm{~mm}$, no clitelo e na região mediana do corpo $9 \mathrm{~mm}$. O número de segmentos é 102. Os maiores exemplares de B medem de $195-240$ $\mathrm{mm}$ e o número de segmentos varia de 122 . 175 respectivamente. O diâmetro anterior varia de $6-9 \mathrm{~mm}$ e na região mediana do corpo de $7-8 \mathrm{~mm}$. A região posterior, incompleta, é achatada dorso-ventralmente e suas medidas variam de $4 \times 6$ a $5 \times 7 \mathrm{~mm}$. Em todos os animais, os dois primeiros segmentos são percorridos por um sulco longitudinal na linha dos nefridióporos. O prostômio de A salienta-se como uma pequena tromba, com vários e profundos sulcos anelares. Na maioria dos exemplares de $B$, o prostômio e os dois primeiros segmentos estão invaginados. O dorso dos animais é de cor vermelha violácea, semelhante à do n. 21 de Séguy (1936); é mais intensa nos intersegmentos e apresenta uma linha de pontos esbranquiçados no equador de cada segmento da região mediana. O ventre é branco cremoso. O limite entre as duas tonalidades situa-se na região das cerdas laterais. Acima das cerdas a cor do dorso dispõem-se em um semicírculo e continua ventralmente, por pequena extensão, no terço posterior de cada segmento. Este limite é especialmente, nítido na região mediana do corpo.

Em A encontra-se um par de papilas crateriformes e de cor branca leitosa nos intersegmentos $6 / 7$ e $7 / 8$, aproximadamente à meia distância entre as linhas de cerdas ventrais e a dos nefridióporos. Outro par de papilas semelhantes encontra-se no equalor de IX, na Iinha dos nefridióporos. Estas papilas representam a abertura dos folículos das cerdas genitais das espermatecas, ao redor dos quais abrem-se tufos glandulares. O clitelo está pouco diferenciado nos segmentos $1 / 2 X V I-1 / 2$ XXV $(=9)$. As cerdas ventrais de XIX XXIV estão envolvidas por papilas glandulares menores do que as dos segmentos das espermatecas. As papilas que circundam as cerdas a de XXI - XXIV e as $b$ de XXIV são crateriformes e de cor branca leitosa. As demais aparecem como uma área circular cremosa, circundada por um halo escuro (Fig. 18). Lateralmente às cerdas $b$ de $1 / 2$ XIX $-1 / 2$ XXIil encontra-se uma dobra (trave pubertal) branca e ondulada, ladeada por outras duas. A dobra externa é formada pela margem do clitelo e a interna pela face ventral, espessada desses segmentos. A face ventral de XIX - XXIII é percorrida por numerosos sulcos longitudinais, mais numerosos no espaço $a b$ de cada lado. $\mathrm{Na}$ metade posterior de XXIV, em aa, há uma ligeira depressão semilunar.

Nos exemplares B, o par de traves pubertais situa-se lateralmente às cerdas $b$ de $\mathrm{XX}-$ $1 / 2$ XXIII, como dois parenteses, envolvendo uma área ligeiramente deprimida, coincidente com o espaço $a b$ de cada lado. Nos animais $\in m$ início de maturação, as traves são retas de $X X-X X I I$. As cerdas ventrais de XIX XXIII são circundadas por papilas glandulares pouco elevadas e de cor branca leitosa. Faltam papilas ao redor das cerdas genitais das espermatecas.

As cerdas dispõem-se em 8 séries longitudinais regulares, iniciando-se as ventrais $\mathrm{em}$ $\mathrm{V}$ ou $\mathrm{VI}$ e as laterais em XX. As cerdas $b$ de VII - IX estão, ora mais ora menos, deslocadas em direção aos poros das espermatecas. Os espaços aa e $a b$ são mais ou menos constantes até XVIII ou XIX. As cerdas $a$ e $b$ de XX - XXIII estão deslocadas em direçăo medial e lateral respectivamente, de modo que o espaço aa é menor e o $a b$ é maior do que nos segmentos adjacentes. As cerdas normais têm a forma de um $\mathrm{S}$ alongado, com um nódulo subme diano, nem sempre bem diferenciado. Seu quarto ou quinto apical é ornamentado por 4 séries de cicatrizes semilunares, dispostas alternadamente. O número de cicatrizes por série varia de $2-4$. O comprimento das cerdas torna-se maior no sentido dorso-ventral e antero-posterior. Em 10 medidas dos exemplares B, o comprimento médio das cerdas da regiäo mediana do corpo é $a, b=930 \mu \mathrm{m}$ e $c, d=681$ $\mu \mathrm{m}$ e na região posterior $a, b=987 \mu \mathrm{m}$ e $c, d=$ $832 \mu \mathrm{m}$. Na região mediana do exemplar A, $a, b$ 

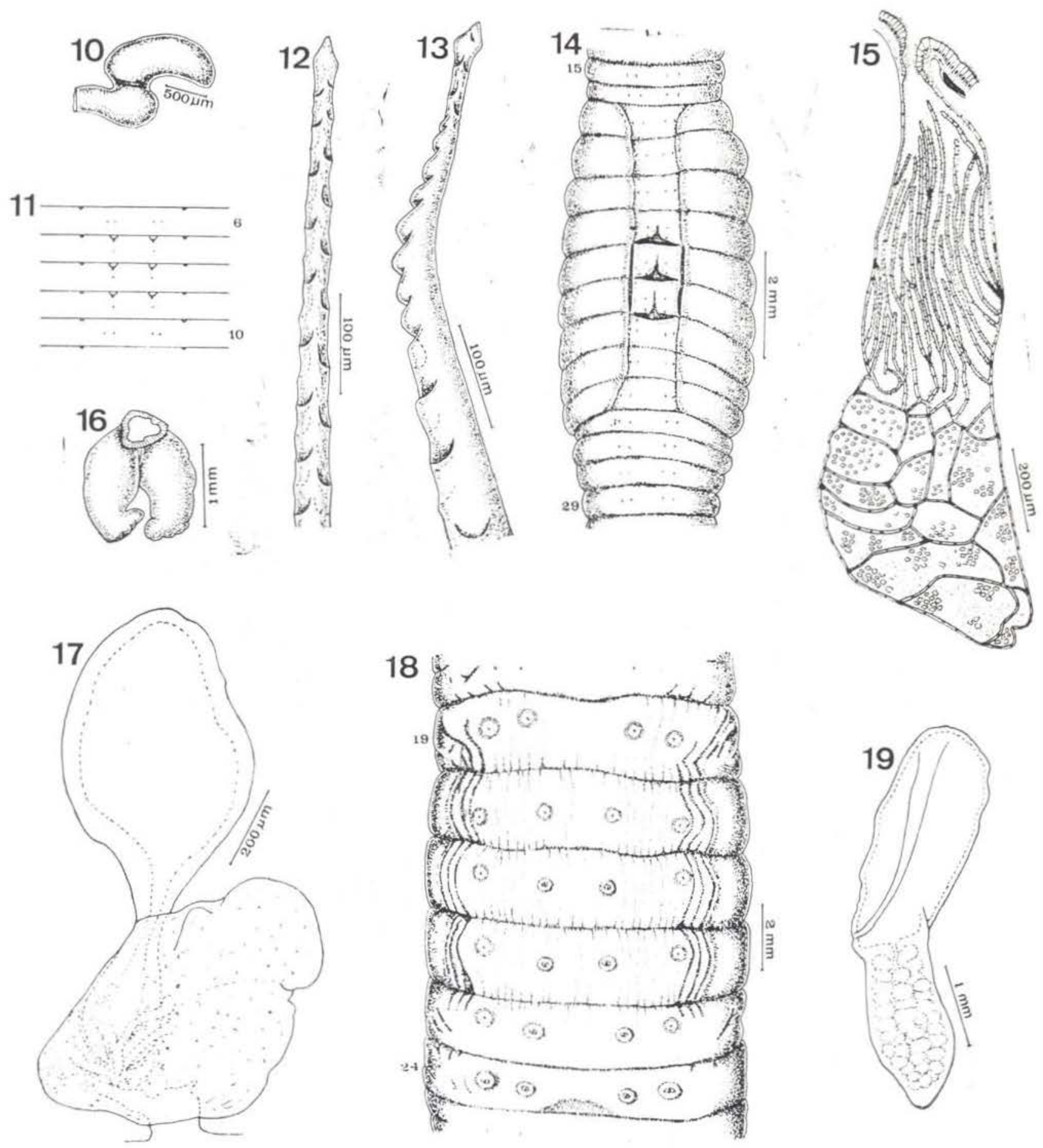

20

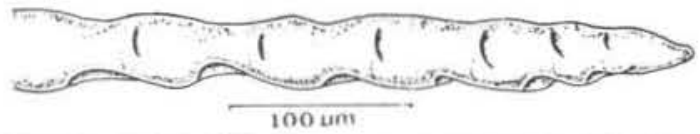

21

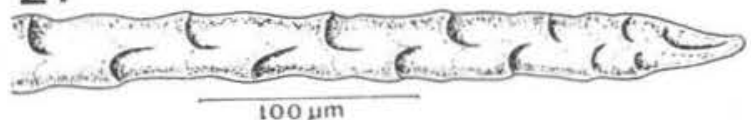

ESTAMPA II - Tuiba tỉpema, sp. n.: 10 - glândula calcifera de VII. Andiorrhinus amazonius Michaelsen, 1918; 11 - esquema da disposiçāo das cerdas nos segmentos VI - X; 12 - ápice de cerda genital de XXII; 13 - ápice de cerda genital de XX; 14 - face ventral de XV - XXIX; 15 - glândula calcífera de VIII em corte sagital algo inclinado; 16 - glândulas calciferas de IX; 17 - espermateca de VII. Andiorrhinus venezuelanus tarumanis, subsp. n.: 18 - face ventral de XIX - XXIV; 19 - espermateca de VIII; 20 - ápice de cerda genital de XX; 21 - ápice de cerda genital de XXII. 
$=1,113 \mathrm{~mm}$ e $c, d=1,055 \mathrm{~mm}$. As relações entre as cerdas nas regiōes mediana e posterior do corpo de 4 animais encontra-se na Tabela 3.

As cerdas $b$ de $\mathrm{VII}-\mathrm{IX}$ e as cerdas $a$ e $b$ de XX - XXIII dos exemplares B e XXIV de A são transformadas em genitais. Estas cerdas são retas em sua maior extensão, com ligeira curvatura na porção mais interna. Seus $2 / 3$ ou $3 / 4$ apicais são ornamentados por 4 séries de cicatrizes opostas 2 a 2, em alturas sucessivas num giro de $180^{\circ}$ (Fig. 21). Por vezes duas séries opostas são mais profundas, dando o aspecto de nós e entre nós (Fig. 20). O número de cicatrizes por série nas cerdas de VII - IX varia de $16-24$, em média 21 e nas de XX - XXIII, XXIV varia de $18-29$, em média 23. A distância entre as cicatrizes sucessivas torna-se menor em direção ao ápice, que termina em ponta ligeiramente curva. A extremidade apical pode ser lisa (Fig. 20) ou, mais freqüentemente, é percorrida por pequenas canaletas originadas pelo prolongamento das últimas cicatrizes (Fig. 21). Em VII - IX de A, o comprlmento das cerdas genitais varia de $2,82-3,59 \mathrm{~mm}$. em média $3,28 \mathrm{~mm}$ e em $B$ de $3,06-5,49 \mathrm{~mm}$, em média $4,20 \mathrm{~mm}$. Em XX - XXIII, XXIV de A variam de $3,41-4,30 \mathrm{~mm}$, em média $3,64 \mathrm{~mm}$ e em $B$ de $2,49-4,89 \mathrm{~mm}$, em média $3,52 \mathrm{~mm}$. Associado a cada folículo de cerda genital em VII - IX de A, há um par de volumosas massas glandulares esbranquiçadas. Em alguns exemplares de B estas formações glandulares estão esboçadas, porém faltam na maioria.
Os septos $6 / 7-10 / 11$ são muito frágeis e de difíci! reconhecimento. Os $11 / 12-15 / 16$ são os mais espessos; os demais são delgados, porém nítidos. Os septos $6 / 7-18 / 19$ têm a forma de cones interpenetrados, os demais são transversais. Logo após a origem, os septos $9 / 10,10 / 11$ e $11 / 12$ fundem-se entre si em vários pontos e correm intimamente acolados até as proximidades do esôfago, onde se fundem entre si segundo uma linha circular. A. porção central destes septos permanece indeppendente, originando duas câmaras infundibuliformes ao redor do esôfago, que correspondem à maior porção das cavidades de $\mathrm{X}$ e XI. $\mathrm{Em}$ cada câmara encontram-se um par de nefrídios, de testículos, de funis seminais, de corações intestinais e de alças nefridiais. Em $A$ as càmaras estão cheias de espermatozóides.

Tufos glandulares de coloraçăo cinzenta salientam-se na cavidade de XIX - XXIV de A. Em cada segmento de XX $-X X I I I$ há, de cada lado, uma massa glandular ovóide e esbranquiçada, separada dos segmentos adjacentes por largas e espessas lâminas musculares transversais, que parecem corresponder à porção ventral dos septos $19 / 20-22 / 23$. Estas formações glandulares faltam ou estão muito pouco diferenciadas em B.

A porção anterior do trato digestivo é alongada e volumosa. A massa faríngea estendese até o segmento $V$. Segue-se o esôfago anterior, que se dilata em um largo papo. Uma moela ampla, globóide e de parede fortemente muscular situa-se em VI, mas pela distenção dos septos anteriores, corresponde externa-

TABELA 3 - Andiorrhinus venezuelanus tarumanis, subsp. n., relações entre as cerdas de 5 exemplares.

\begin{tabular}{|c|c|c|c|c|c|c|c|c|c|c|c|c|c|c|c|c|c|c|}
\hline \multirow{2}{*}{ Exemplar } & \multicolumn{9}{|c|}{ Segmentos XLV - LV } & \multicolumn{9}{|c|}{ Segmentos CXLV - CLV } \\
\hline & aa & : & $\mathbf{a b}$ & : & bc & : & cd & : & dd & aa & $:$ & $\mathbf{a b}$ & : & bc & : & cd & : & dd \\
\hline A & 5,83 & : & 1,00 & : & 6,38 & : & 0,50 & : & 18,33 & $\ldots$ & & $\ldots$ & & $\ldots$ & & $\ldots$ & & $\ldots$ \\
\hline$B_{1}$ & 8,33 & : & 1,00 & : & 10,83 & : & 0,83 & : & 27,50 & 9,00 & : & 1,00 & : & 7,00 & : & 0,60 & : & 20,40 \\
\hline $\mathrm{B}_{2}$ & 6,66 & : & 1,00 & : & 6,93 & : & 0,46 & : & 18,93 & 9,00 & : & 1,00 & : & 8,60 & : & 0,80 & : & 20,80 \\
\hline $\mathbf{B}_{3}$ & 9,60 & : & 1,00 & : & 12,40 & : & 0,60 & : & 32,80 & 8,20 & : & 1,00 & : & 9,50 & : & 0,60 & . & 21,60 \\
\hline $\mathrm{B}_{4}$ & 5,66 & : & 1,00 & : & 9,50 & : & 0,75 & : & 23,50 & 7,00 & : & 1,00 & : & 9,00 & : & 0,70 & : & 21,70 \\
\hline Média & 7,22 & : & 1,00 & : & 9,21 & : & 0,63 & : & 24,21 & 8,30 & : & 1,00 & : & 8,52 & : & 0,67 & : & 21,12 \\
\hline
\end{tabular}


mente aos segmentos XI e XII. Em VII - IX encontram-se três pares de glândulas calcíferas aproximadamente do mesmo tamanho e de origem ventro-lateral no esôfago. As glânaulas são piriformes, com longo pescoço e sem apêndice terminal. Desenvolvem-se para a frente e para cima, de modo que sua porção ental, mais volumosa, situa-se sobre o esôfago. Sua estrutura é do tipo de saco lamelar (Lamellentasche). As lamelas são longitudinais e dorso-ventrais; fundem-se entre si em vários pontos e ramificam-se na periferia, especialmente na regiáo ental. O número de lamelas varia de $23-30$, sendo o número menor encontrado na porção proximal, mais afilada das glândulas, onde também é menor o número de fusões. O intestino inicia-se em XXV. O tiflosole surge em XXVI, cresce para trás e em XXVIII já apresenta a forma normal, posterior. de uma lâmina dorsal, larga e dobrada como um $\mathrm{S}$ apertado. Cecos intestinais faltam.

Em cada segmento a partir de II, há um par de holonefrídios, que se abre por um esfincter musculoso, em série com as cerdas $d$. As alças dos nefrídios de II - VI formam um enovelado de cada lado do esôfago anterior. Neste emaranhado nefridial inicia-se o par de vasos extra-esofágicos que, logo após a moela, funde-se entre si, constituindo um vaso único, aderido à linha média ventral do esôfago posterior até o segmento XXV. O vaso supra-esofágico situa-se na linha média dorsal do esôfago, nos segmentos VII - XIV. É especialmente volumoso em X - XIII, de onde partem 4 pares de corações intestinais, que o comunicam com o vaso ventral. O vaso dorsal é único; forma pequenas alças irregulares sobre o esôfago posterior e termina por uma bifurcação que se capilariza na face posterior da moela. Três pares de corações laterais unem o vaso dorsal com o ventral em VII - IX. Os outros dois troncos longitudinais, os vasos ventral e subneural, são simples e retilíneos; o subneural é o mais delgado.

Dois pares de testículos e de funis seminais situam-se em X e XI, no interior de sacos testiculares descritos acima. As vesículas seminais do segundo par são livres e volumosas "em XII, podendo continuar-se por um pequeno apêndice lateral em XIII. As do primeiro par, pouco menores, situam-se no interior dos sacos testiculares de XI. Os dois canais deferentes de cada lado correm para trás lado a lado, sobre a parede do corpo, até $18 / 19$. A seguir penetram na musculatura longitudinal, seguem uma trajetória descendente e seu diâmetro torna-se sucessivamente maior. Um par de pequenas câmaras piriformes, revestidas por fraca capa muscular, situa-se no interior da musculatura parietal, na metade posterior de XIX. Um septo horizontal divide cada câmara em duas cavidades e cada uma das quais recebe um canal deferente. O epitélio das câmaras, como o dos canais deferentes, é bastante ciliado. Com o desaparecimento do septo no quinto ectal de cada câmara, as duas cavidades confluem em um duto curto, que se abre pelo poro masculino no intersegmento $19 / 20$. em série com $b$. Os ovários aparecem como um par de lâminas largas, com a margem livre sinuosa e composta por várias faixas de ovos em diferenciação. Situam-se em XIII, mas devido à forma dos septos, correspondem externamente ao segmento XVII. O par de ovidutos abre-se por poros microscópicos na região posterior de XVIII, próximo ao intersegmento $18 / 19$, pouco para fora da linha de cerdas $b$. Três pares de espermatecas situam-se em VII - IX, abrindo-se por poros irreconheciveis externamente, nos intersegmentos $6 / 7$ $8 / 9$, em série com os nefridióporos. Em A, as espermatecas são aproximadamente do mesmo tamanho; em B, tornam-se nitidamente maiores no sentido antero-posterior $(1<2<3)$. Em cada espermateca, a ampola é piriforme ou tubular, achatada e com pregas que lhe dão um aspecto ligeiramente torcido (Fig. 19). O duto é tão longo quanto a ampola e está parcialmente mergulhado na parede do corpo. A parede do duto é espessa e no seu interior situam-se. numerosas câmaras seminais arredondadas ou ovóides.

\section{CONSIDERAÇÕES}

Andiorrhinus venezuelanus tarumanis, subsp. $\mathrm{n}$. distingue-se de $A$. v. venezuelanus (Cognetti, 1908) conhecido da Venezuela, Escorial, pelos seguintes caracteres: A. v. tarumanis - cerdas genitais com $16-29$ cicatrizes por série A. v. venezuelanus - com $50-90$ ); último par de corações em XIII (em XII). 
A. pictus Michaelsen, 1926 conhece-se unicamente pela descrição original, incompleta, de animais provenientes de Manaus e Manacapuru. Michaelsen (1926: 285) separa seus animais de $A$. venezuelanus pela cor, extensão do clitelo e pelo aparelho glandular associado às cerdas genitais das espermatecas. Em nossos animais, a cor é semelhante à de pictus e a extensão do clitelo é intermediária entre pictus e venezuelanus. Em pictus ocorrem tufos glandulares associados às cerdas genitais de VII e VIII em venezuelanus de VII - IX. Em vários de nossos animais, que embora tenham cerdas genitais, faltam tufos glandulares associados; talvez devido ao estado de maturação. $\mathrm{O}$ número de cicatrizes por série nas cerdas genitais de nossos animais é próximo do de pictus e bastante afastado do de venezuelanus. É possível que esta diferença se deva a diferente método de contagem usado por Cognetti. O único caracter que ainda separa as duas espécies é a presença de cerdas genitais nos segmentos VII e VIII de A. pictus e VII - IX de A. venezuelanus.

Andiorrhinus caudatus, sp. $\mathrm{n}$. (Figs. 22 - 27)

\section{MATERIAI}

BRASIL, Amazonas: Sucunduri (margem do rio Sucunduri próximo à estrada Transamazônica), 15 exemplares clitelados (10 sem a extremidade posterior), 5 maduros aclitelados e 9 jovens (INPAZ-32A-B), A. F. Santos, E. O. Rufino e G. Righi col. 29/6/1975. Estrada Manaus-Itacoatiara Km 26 (Reserva Ducke), igarapé do Barro Branco, 1 exemplar clitelado, 17 maduros aclitelados e 17 jovens (INPAZ-35), E. F. Nascimento col. $9 / 5 / 1975 ; 20$ exemplares clitelados (14 sem a extremidade posterior) (INPAZ-34), I. Ayres e E. F. Nascimento col. 25-26/8/1975.

$\mathrm{Na}$ descrição abaixo os animais das duas procedências serão designados por A e B respectivamente.

Em A o comprimento varia de $90-105$ $\mathrm{mm}$ e em $\mathrm{B}$ de $120-155 \mathrm{~mm}$. O diâmetro varia, na região anterior de $A$ entre $2,0-3,0 \mathrm{~mm}$, cle $B$ entre $2,3-3,0 \mathrm{~mm}$, no clitelo de $A$ entre $3,0-4,0 \mathrm{~mm}$, de $B$ entre $3,6-5,0 \mathrm{~mm}$ e na região dos segmentos $X L-L$ de $A$ entre 2,0 $-3,0 \mathrm{~mm}$ e de $B$ entre $2,4-3,0 \mathrm{~mm}$. A partir da região mediana do animal, o corpo, que ena cilíndrico, achata-se dorso-ventralmente. O achatamento é mais acentuado na face dorsal, que se torna plana entre as cerdas $d$. Em alguns animais, talvez devido à fixação, o espaço $d d$ apresenta-se curvo como uma canaleta. Pigmento falta; a cor cinza clara geral do corpo é devida ao conteúdo intestinal; o clitelo é amarelo pálido, semelhante ao n. ${ }^{\circ} 330$ de Séguy (1936) . O número de segmentos varia em $A$ de $227-242$ e em B de $205-289$. Os seginentos I - III têm a superfície percorrida por fracos sulcos longitudinais, que se tornam merios nítidos para trás. Os segmentos IV IX sãc unianelares ou fracamente trianelares, com o ânulo mediano mais elevado. Os demais segmentos até a região mediana do corpo, são nitidamente trianelares, com o ânulo mediano mais elevado e os outros dois percorridos ou não por um sulco transversal que os divide ao meio. Para trás os segmentos tornam-se sucessivamente mais curtos e a anelação secundária pouco evidente. Uma área retangular. espessa e de superfície rugosa ocupa o espaço aa de $4-5$ segmentos, iniciando-se entre os segmentos LXXXIII - CXII em $A$ e entre os $\mathrm{Cl}-\mathrm{ClII}$ em B. Esta região é de tonalidade rósea-acastanhada devido ao acúmulo de sangue e corresponde à chamada "Zona Caudal" conhecida de Pontoscolex corethrurus (Eisen, 1900: 87; Righi \& Bittencourt, 1972: 160), Andioscolex antunesi (Righi, 1971: 58) e Meroscolex marcusi Righi \& Ayres, 1976: 258).

O clitelo ocupa os segmentos XVI - XXV $(=10)$. E em forma de anel; a face dorsal é mais espessa e seu limite inferior pode aparecer como um sulco longitudinal e irregular, pouco lateral às cerdas $b$. Um par de traves pubertais esbranquiçadas e com a forma de paralelepipedo, mais volumosa nos exemplares de A, situa-se no espaço $a b$ de XXI - XXIV. Um sulco longitudinal percorre o ângulo interno das traves. A face ventral de XX e XXV espessa-se transversalmente isolando entre si $\varepsilon$ as traves pubertais, uma área quadrangular, ventral e mediana (Fig. 22). A face ventral dos segmentos VII - IX é espessada e de cor branca, porém o espessamento não tem contorno bem definido. Na maioria dos exemplares de $\mathrm{B}$ há um espessamento semelhante, mas de contornos bem definidos em XI; em alguns 

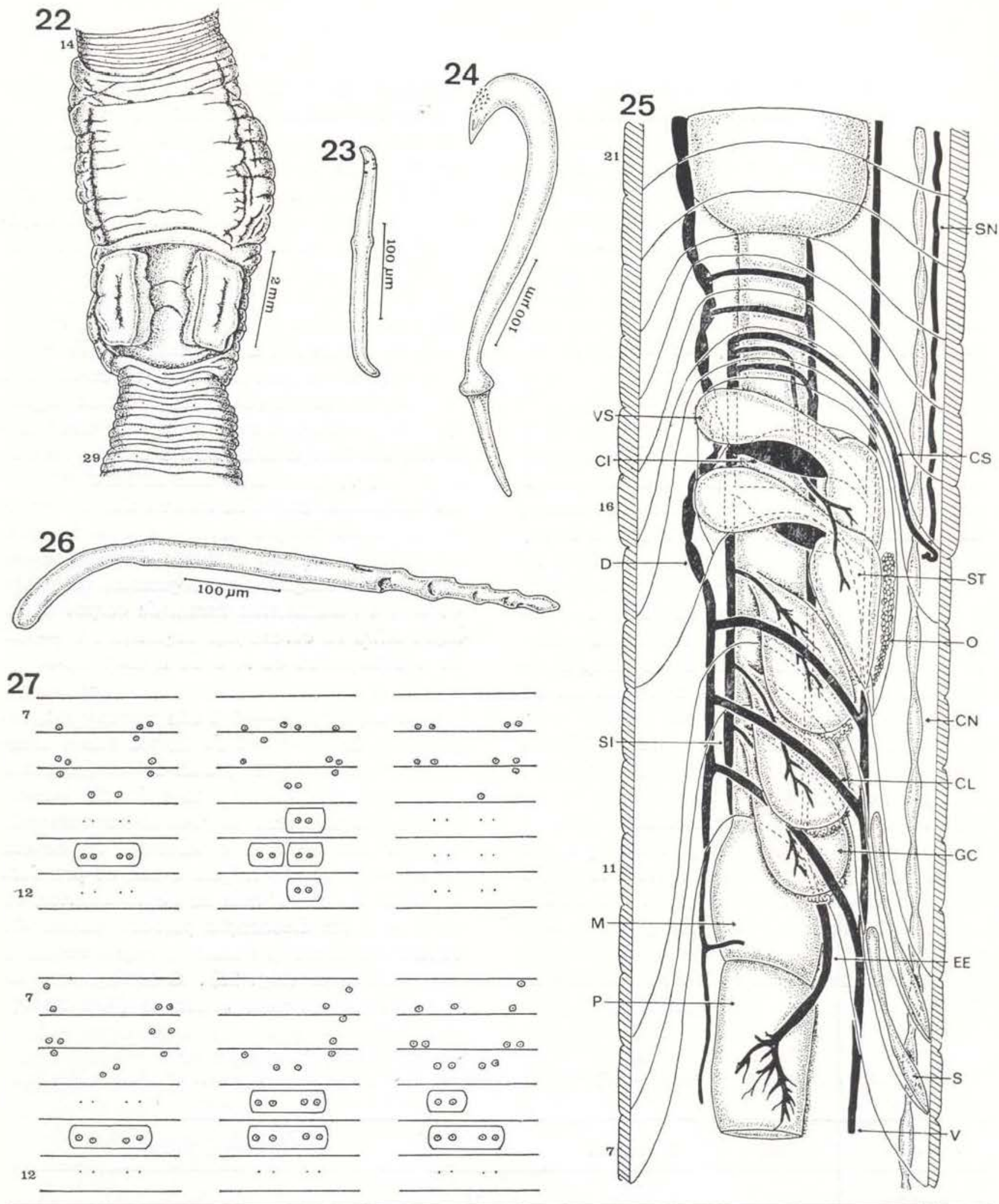

ESTAMPA III - Andiorrhinus caudatus, sp. n.: 22 - face ventral dos segmentos XIV - XXIX; 23 - cerda d da região mediana do corpo; 24 - cerda d da região posterior do corpo; 25 - esquema da organização dos segmentos VI - XXI; 26 - cerda genital de VIII; 27 - esquema da disposição das cerdas e papilas pubertais nos segmentos VII - XII de 6 exemplares da Reserva Ducke. (CI = coração intestinal; $\mathrm{CL}=\mathrm{CO}-$ ração lateral; $\mathrm{CN}=$ cordão nervoso; $\mathrm{CS}=$ vaso comissural-subneuro-supraintestinal; $\mathrm{D}=$ vaso dorsal; $\mathrm{EE}$; vaso extra-esofágico; $\mathrm{GC}=$ glândula calcífera; $\mathrm{M}=$ moela; $\mathrm{O}=$ ovário; $\mathrm{P}=$ papo; $\mathrm{S}=$ espermateca; $\mathrm{SI}=$ vaso supra-intestinal; $\mathrm{SN}=$ vaso subneural; $\mathrm{ST}=$ saco testicular; $\mathrm{V}=$ vaso ventral; $\mathrm{VS}=$ vesícula seminal). 
destes animais ocorre estrutura semelhante no ventre do segmento $X$ ou apenas em um dos lados de X e XI (Fig. 27). No interior desses espessamentos encontram-se papilas circulares ao redor das cerdas ventrais. Os poros genitais são bem reconheciveis apenas em cortes. O par de poros masculinos situa-se no interior das traves pubertais, no terço posterior de XXI, em série com a. Os poros femininos localizam-se no terço posterior de XVI, em linha $\operatorname{com} b$. Dois pares de poros de espermatecas, também inconspícuos, encontram-se em $7 / 8$ e $8 / 9$, em série com $b$.

As cerdas ventrais iniciam-se em IV ou V e as laterais em VI ou VII. As cerdas comuns são quase retas, com as extremidades curvas em sentidos opostos e um nódulo submediano, mal definido (Fig. 23). A porção apical. curva, é ornamentada por 4 séries alternas de 2 cicatrizes, porém nem sempre as cicatrizes têm disposição regular. Nos segmentos anteriores até o $L$ ou LXX, as cerdas $d$ têm forma semeIhante às das demais séries e seu comprimento médio é de $240 \mu \mathrm{m}$ em A e $250 \mu \mathrm{m}$ em B. Para trás, algumas cerdas $d$ são em forma de gancho, com um nódulo bem diferenciado no terço basal e a porção apical curva e ornamentada por numerosos espinhos pequenos (Fig. 24). A partir da região compreendida entre os seginentos LXXX - CV, todas as cerdas $d$ são em forma de gancho e seu comprimento médio é de $440 \mu \mathrm{m}$ em A e $615 \mu \mathrm{m}$ em B. As cerdas de VII - IX transformam-se em genitais; tammém as de XI na maioria dos exemplares äe $\mathrm{B}$ e esporadicamente as de X e XII. Estas cerdas são retas em sua maior parte, com ligeira curvatura no quarto ental e seu comprimento médio é de $562 \mu \mathrm{m}$ em A e $633 \mu \mathrm{m}$ em B. Seu terço apical é ornamentado por 4 séries alternas de cicatrizes côncavas, abertas para o ápice e de margem sinuosa. O número de cicatrizes por série varia de $4-5$ (Fig. 26). A aispo. sição destas cerdas em VII - IX é variável; €m geral estão deslocadas para as vizinhanças dos poros das espermatecas (Fig. 24). O uspaço $b c$ aumenta do segmento $X$ até o clitelo. onde as cerdas são dificilmente reconheciveis. Nos segmentos post-clitelares, as cerdas $a, b$ e $c$ dispõem-se em séries longitudinais regulares; as $d$ situam-se mais ou menos alternadamente em duas alturas, mas a alternància não é regular, podendo haver dois ou mais segmentos sucessivos com $d$ na mesma altura. A partir da região compreendida entre os segmen. tos LXXX - CV, as cerdas $d$ dispõein-se em duas séries longitudinais regulares, coincidindo com o achatamento dorsal do corpo. A re lação entre as cerdas nos segmentos $\mathrm{C}-\mathrm{CX}$ de 4 exemplares de $A$ e de $B$ encontra-se na Tabela 4.

Os septos $6 / 7-8 / 9$ são musculosos, espessos e com a forma de longos cones interpenetradios. O $9 / 10$ prende-se ventralmente junto ao intersegmento $9 / 10$ e dorsalmente no 13/14; é espesso nas porções dorsal e laterais e frágil nas mediana e ventral. Os septos $10 / 11-13 / 14$ são frágeis e não se prenciem à parede do corpo, mas ao septo anterior, de modo que em dissecação parecem faltar. Os septos seguintes prendem-se regularmente à parede do corpo (Fig. 25) . O esôfago anterior dilata-se em um papo volumoso (Fig. 25, P),

TABELA 4 - Andiorrhinus caudatus, sp. n., relações entre as cerdas nos segmentos C.CX de 8 exemplares

\begin{tabular}{|c|c|c|c|c|c|c|c|c|c|c|c|c|c|c|c|c|c|c|}
\hline \multirow{2}{*}{$\begin{array}{l}\text { Procedêncin } \\
\text { Exemplar }\end{array}$} & \multicolumn{9}{|c|}{ Sucunduri } & \multicolumn{9}{|c|}{ Reserva Ducke } \\
\hline & aa & : & $a b$ & : & be & : & cd & : & dd & aa & : & $\mathbf{a b}$ & : & be & : & cd & : & dad \\
\hline 1 & 1,47 & : & 1,00 & : & 1,05 & : & 0,82 & : & 2,58 & 1,85 & : & 1,00 & : & 1,42 & : & 1,02 & : & 3,23 \\
\hline 2 & 1,57 & : & 1,00 & : & 1,24 & : & 1,13 & : & 2,31 & 1,93 & : & 1,00 & : & 1,47 & : & 0,84 & : & 3,04 \\
\hline 3 & 1,88 & : & 1,00 & : & 1,11 & : & 1,44 & ; & 2,48 & 1,89 & : & 1,00 & : & 1,42 & : & 0,86 & : & 3,26 \\
\hline 4 & 1,66 & : & 1,00 & : & 1,24 & : & 1,15 & : & 2,53 & 1,90 & : & 1,00 & : & 1,52 & : & 0,86 & : & 3,12 \\
\hline Média & 1,64 & : & 1,00 & : & 1,16 & : & 1,13 & : & 2,47 & 1,89 & : & 1,00 & : & 1,45 & : & 0,88 & : & 3.16 \\
\hline
\end{tabular}


que se abre em uma moela (M) mais ou menos globóide e fortemente muscular em VI. Três pares de glândulas calciferas (GC) abrem. se dorso-lateralmente no esôfago nos segmentos VII - IX. As glândulas são aproximadamente do mesmo tamanho, mais ou menos piriformes e com pequeno apêndice terminal, de aspecto botrioidal. A estrutura das g!ândulas é do tipo de saco lamelar (Lamellentasche); em sua porção mediana o número de lamelas varia de $19-25$. Na porção ental de caria glândula, algumas lamelas reunem-se am tubos pequenos e sinuosos, de fundo cego, que formam o apêndice. $O$ intestino inicia-se em XIX. O tiflosole apresenta-se a partir de XXVI ou XXVII, como uma lâmina dorsal, larga e com a margem livre dobrada. Cecos intestinais faltam.

O vaso dorsal (D) e simples; nos segmentos XVIII - XIV curva-se em S e continua mais su menos retilíneo até a massa faríngea. Na região anterior da moela, o vaso dorsal emite um par de ramos. Comunica-se com o vaso ventral (V) por três pares de coraçōes laterais (CL) nos segmentos VII - IX e com o vaso extra-esofágico (EE) por dois pares de vasos transversais em XVI e XVII. Dois pares de corações intestinais $-(\mathrm{CI})$ situam-se em $\mathrm{X}$ e XI. parcialmente envolvidos pelos sacos testiculares (ST). Uma alça comissural une o vaso extra-esofágico em XIII ao supra-intestinal em XIV. Em XV o vaso supra-intestinal (SI) recebe um par de vasos volumosos provenientes dos sacos testiculares e a seguir termina no par de vasos comissurais subneuro-supra-intestinais (CS). O vaso subneural (SN) é sinuoso e igual ou pouco mais volumoso do que o ventral; inicia-se em XV a partir da ligação com os comissurais subneuro-supra-intestinais, falta anteriormente. O par de vasos extra-esofági$\cos$ (EE) inicia-se por uma reunião de capilares de cada lado do papo e corre dos lados da moela; funde-se entre si logo após a moela, formando um vaso único situado sob o esôfago. As ligaçōes entre os vasos longitudinais, exceto os corações, foram estudadas unicamente nos exemplares de B, que se apresentam meIhor conservados. Em cada segmento há um par de holonefrídios, cujos nefridióporos, dotados de esfincter musculoso, situa-se em série com as cerdas $c$, nos segmentos post-clitelares.

Dois pares de sacos testiculares encontram-se em X e XI. Os simétricos fundem-se ventralmente entre si e envolvem o vaso ventral e a porçäo basal dos corações intestinais. Em B, os sacos testiculares (Fig. 25, ST) são látero-ventrais, comunicando-se com dois pares de vesículas seminais (VS) bem diferenciadas em XI e XII. Em A, os sacos testiculares desenvolvem-se látero-dorsalmente e as vesículas seminais sāo proporcionalmente menores e ma! ' itintas, ficando as do primeiro par envolvidas parcialmente pelos sacos testiculares de XI. O par de canais deferentes de cada lado é sinuoso e corre no interior da musculatura parietal longitudinal. Na rzgiăo anterior do segmento XXII, o par de canais de cada lado abie-se em uma pequena câmara situada no interior da musculatura parietal. Cada câ. mara é revestida por epitélio cilíndrico e dotada de fina capa muscular circular. De sua porção ventral parte um curto duto terminal, revestido por epitélio cúbico como o dos canais deferentes, que se abre na superfície como o par de poros masculinos. Um par de ovários (O), com a forma de uma lâmina larga, iongà e fina, situa-se em XIII, mas devido à forma dos septos, sua posição é ventral aos sacos testiculares. Dois pares de espermatecas encontram-se em VIII e IX. Em cada espermateca o duto é muito curto e acha-se totalmente mergulhado na parede do corpo. A ampola é tubular, mais ou menos achatada, com a porção basal mais larga do que a apical. Nos animais de B, as espermatecas dos dois pares são aproximadamente do mesmo tamanho e quase retilineas. Nos animais de A, as espermatecas de IX são pouco maiores e mais ou menos retilíneas, as de VIII em geral menores e dobradas em cotoveio.

\section{CONSIDERAÇÕES}

$\mathrm{Na}$ Reserva Ducke, um de nós (1. Ayres) encontrou os animais nas margens e no fundo do igarapé do Barro Branco. Nos dois biótopos os animais encontravam-se com a porção anterior, cilíndrica, do corpo no interior de uma galeria no lodo, e a posterior, achatada e com cerdas em gancho, estendida na superfície. 
Em Sucunduri todos os animais foram coletados no interior de galerias, num barranco periodicamente inundado da margem do rio Sucunduri, onde desemboca um pequeno igarapé. As pequenas diferenças encontradas entre os animais das duas procedências foram interpretradas como devidas a variações populacionais de uma única espécie.

Andiorrhinus caudatus, sp. n. distingue-se das demais 12 espécies conhecidas do gênero (Righi, 1971: 71) pelo número e organização das espermatecas e pela posição e forma das traves pubertais e das cerdas.

Andiodrilus icomi Righi, 1971

Andiodrilus icomi Righi, 1971: 36, figs, 51-56.

\section{MATERIAL}

BRASIL, Amazonas: Janauacá, lago Castanho, em solo de ilha de terra firme coberto por mata secundária, 5 exemplares (1 clitelado) (INPAZ-5), I. Ayres col. 2/5/1974; margem do lago, supercialmente em solo rico de detritos orgânicos, 7 exemplares (2 clitelados) (INPAZ-6), I. Ayres col. 10/10/1974; 18 exemplares (2 clitelados) (INPAZ-7), I. Ayres col. 6/11/1974. Margem de igapó próximo à foz do rio Tarumă-mirim, 16 exemplares ( 6 clitelados) (INPAZ-31), G. Righi, E. Rufino e H. Schubart. col. 2/7/1975.

Andiodrilus icomi é a única espécie do gênero conhecida do Brasil e indicada até agora apenas da localidade tipo, Amapá: serra do Navio. À descrição original devemos acrescentar que as cerdas genitais $a$ e $b$ dos segmentos das espermatecas podem ocorrer em um dos segmentos de VII - IX e as $c$ e $d$ faltam ou não estão transformadas em genitais.

Rhinodrilus brasiliensis buritis, subsp. $\mathrm{n}$. (Figs. 28-32)

\section{MATERIAL}

BRASIL, Amazonas: estracia Manaus-Itacoatiara, Km 26 (Reserva Ducke) próximo ao igarapé do Barro Branco, em solo com palmeiras Mauritia sp.. 3 exemplares clitelados (INPAZ-39), I. Ayres e E. F. Nascimento col. 9/5/1975; em troncos podres, 8 exemplares (3 clitelados) (INPAZ-40), L. Antony, E. Rufino, E. M. Froehlich e G. Righi col. 23/6/1975. Próximo a igarapé do rio Cuieiras, no solo, 2 exemplares (1 clitelado) (INPAZ-57), I. Ayres col. $8 / 4 / 1975$.
O comprimento dos animais clitelados varia de $40-55 \mathrm{~mm}$ e o diâmetro na região anterior de $2,0-2,7 \mathrm{~mm}$, no clitelo de $2,3-2,6$ $\mathrm{mm}$, na região mediana do corpo de $1,8-2,4$ $\mathrm{mm}$ e na região posterior de $1,6-2,1 \mathrm{~mm}$. O número de segmentos varia de $81-96$. O primeiro segmento é rudimentar, invaginável e sem pigmento; o comprimento do segundo é cerca de 3 vezes menor do que o do terceiro. Os dois primeiros segmentos são percorridos por um par de sulcos longitudinais na linha dos riefridióporos. Os demais segmentos apresentam um sulco equatorial dorsal, especialmente nítido nos segmentos post-clitelares. $O$ prostômio é tentaculiforme. A cor do dorso é azul acinzentada, semelhante à do n. 528 de Séguy (1936) e o ventre branco cremoso; o limite entre as duas tonalidades é gradual na linha de cerdas laterais. O clitelo é laranja claro como o n. 190.

O clitelo é em forma de sela, sem limites ventrais bem definidos e ocupa os segmentos $X V-X X V(=11)$ em 3 animais, os XV $\operatorname{XXIV}(=10)$ em 2 e os $1 / 2$ XV $-1 / 2$ XXV $(=10)$ em 2 outros. Papilas pubertais faltam em um dos exemplares; nos demais aparecem como pequenas áreas circulares ao redor das cerdas ventrais do segmento XXIV, podendo ocorrer também nos segmentos XVI ou XVIII. Traves pubertais aparecem como duas faixas largas, com a margem lateral mais entumescida situada ao lado das cerdas $b$, nos segmentos $1 / 2$ XIX $-1 / 3$ XXIV em 5 exemplares e nos $1 / 2$ XIX $-X X I I I$ em 2 outros. As cerdas têm distribuição lumbricina e iniciam-se no segmento II ou IV. As cerdas normais sắo sigmóides, com ligeiro espessamento submediano (Fig. 28). O ápice é ornamentado por algumas cicatrizes largas e côncavas, distribuídas irregularmente, mas em geral mais numerosas e profundas na porção côncava da cerda (Fig. 29). Em dois animais as relações entre as cerdas na região mediana do corpo (segmentos $\mathrm{XXX}-\mathrm{XXXV)}$ é $a a: a b: b c: c d: d d=7,5$ : $1,0: 7,5: 1,0: 28,6=5,1: 1,0: 6,4: 1,0: 21,7$ e na região posterior (segmentos $L X V-L X X$ ) aa $: a b: b c: c d: d d=4,3: 1,0: 4,3: 1,0:$ $13,8=3,7: 1,0: 3,7: 1,0: 10,2$ respectivamente. As cerdas ventrais do segmento XXIV e do XVI, XVII ou XVIII são transformadas em genitais. Estas cerdas têm a forma de um $\mathrm{S}$ alon- 

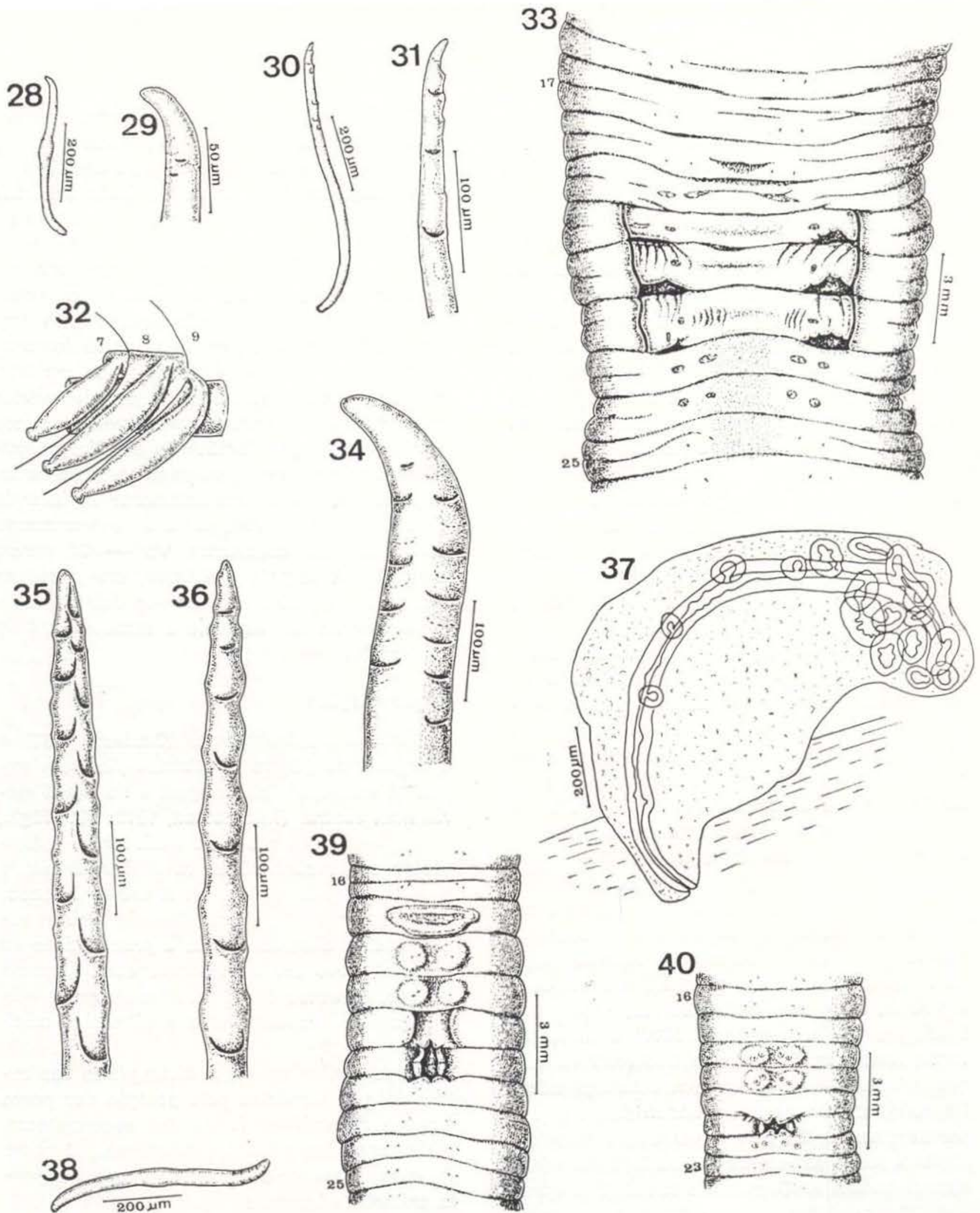

ESTAMPA IV - Rhinodrilus brasiliensis buritis, subsp. n.: 28 - cerda ventral posterior; 29 - ápice da mes ma; 30 - cerda genital do segmento XXIV; 31 - ápice da mesma; 32 - esôfago e glândulas calciferas esquerdas, reconstrução parcial de cortes seriados. Rhinodrilus lucilleae, sp. n.: 33 - face ventral de XVII - XXV: 34 - ápice de cerda ventral da região mediana do corpo; 35 - ápice de cerda genital de XX; 36 - idem de outro animal; 37 - espermateca de VII. Rhinodrilus curiosus, sp. n.: 38 - cerda ventral posterior; $39-$ fa. ce vêntral de XVI - XXV de um animal clitelado; 40 - face ventral de XVI - XXII de um animal acli. telado. 
gado (Fig. 30), com o terço apical ornamentado por 2 séries de cicatrizes semilunares (Fig. 31). O número de cicatrizes por série varia de $4-5$.

Os sepios anteriores até o $12 / 13$ são multo tênues e com a forma de cones interpenetrados, individualizados apenas em cortes. Os septos posteriores são bem definidos em dissecação e dispostos transversalmente. Do trato digestivo reconhece-se uma moela piriforme e musculosa no segmento VI. Três pares de glândulas calcíferas situam-se nos segmentos VII - IX. As glândulas são elípticas, com um pequeno estrangulamento subapical isolando um pequeno apêndice terminal arredondado. Sua estrutura é do tipo tubular composto (Kompositenschlauchtasche) nos dois primeiros pares; as do terceiro par são alveolares (Wabentasche) ou ligeiramente trabeculares (Leistentasche). No segmento VIII o esôfago emite um divertículo dorsal e mediano, com o qual se comunica por larga fenda; o divertículo continua-se como um saco cego em VII. O revestimento interno do divertículo é liso, contrastando com o do esôfago, que apresenta numerosas dobras. Os dois primeiros pares de glândulas calcíferas abrem-se de cada lado da linha média dorsal do divertículo em VII e VIII, respectivamente. As do terceiro par abremse por pequeno duto na região basal e postevior do divertículo, junto ao septo $8 / 9$. As glândulas tornam-se maiores do primeiro ao terceiro par e dispõem-se de modo a recobrirem-se parcialmente no mesmo sentido (Fig 32). O intestino inicia-se em $X V$ e o tiflosole em XXVI, como uma lâmina dorsal, larga e dobrada em S. No segmento XXVI o intestino forma duas pequenas saculações ventrais, largas e curtas, com a margem esbranquiçada. Os nefrídios são do tipo holonefridial, um par por segmento. Os nefridióporos são reconhecíveis a partir do intersegmento $2 / 3$, em série com as cerdas $d$. O aparelho circulatório apresenta 3 pares de coraçōes laterais nos segmentos VII - IX e 2 pares de corações intestinais volumosos em $\mathrm{X}$ e XI.

Dois pares de sacos testiculares encontram-se em X e $\mathrm{XI}$; os simétricos fundem-se ventralmente?. Os sacos desenvolvem-se lateralmente, recobrindo os corações; os de XI recobrem também o primeiro par de vesículas seminais. As vesículas do segundo par são pouco diferenciadas em XII, atravessam u septo $12 / 13$ e alargam-se látero-dorsalmente ao esôfago em XIII. O par de dutos seminais cie cada lado funde-se entre si na altura oo segmento XIV. O duto único resultante de cada lado corre retilinearmente para trás, no interior da musculatura longitudinal, logo aba!xo do peritônio. Na região posterior do segmento XX, cada duto perfura a parede do corpo para abrir-se no intersegmetno $20 / 21$, no interior das traves pubertais. Um par de ovários espatuliformes prende-se ventralmente na face posterior do septo 12/13. Os dois largos ovidutos abrem-se por poros microscópicos no intersegmento $14 / 15$, imediatamente ao lado da linha de cerdas $b$. Três pares de espermatecas situam-se nos segmentos VII - IX, sendo $1<2<3$. A ampola é tubular, ora mais ora menos curva e bem separada do delgado duto. cujo comprimento equivale a cerca de $1 / 4$ do da ampola.

\section{CONSIDERAÇÕES}

Rhinodrilus brasiliensis (Benham, 1887) é a espécie do gênero de distribuição mais ampla. É assinalada no Paraguai e no Brasil meridional, central (Michaelsen, 1918: 181; Righi, 1974: 554) e agora setentrional. Duas subespécies são reconhecidas, $R$. b. brasiliensis e R. b. teres (Ude, 1894) . R. b. brevis Omodeo, 1955 da Venezuela, Rancho Grande, embora sumariamente descrita devido à precariedade do material, deve ser considerada como espécie à parte, diferindo de $R$. brasiliensis pelas cerdas genitais, espermatecas e glândulas calciferas.

R. b. buritis, subsp. n. distingue-se das outras duas subespécies pela posição dos poros genitais masculinos, forma das espermatecas e aberturas das glândulas calcíferas. O nome da nova subespécie deriva do nome indígena da palmeira Mauritia sp (buriti) .

Rhinodrilus lucilleae, sp. $\mathrm{n}$. (Figs, $33-37$ )

\section{MATERIAL}

BRASIL, Amazonas: Sucunduri (Estrada Transamazônica, trecho Humaitá-Jacareacanga, Km 523), €m solo arenoso da praia de um igarapé, periodi- 
camente inundado, 1 exemplar clitelado sem a extremidade posterior, 2 maduros aclitelados (1 sem \& extremidade posterior) e 2 jovens (INPAZ-46), L. Antony e G. Righi col. 28/6/1975.

O exemplar aclitelado, maduro e completo mede de comprimento $380 \mathrm{~mm}$ e de diâmetro na região anterior e média $12 \mathrm{~mm}$ e na região posterior; que é ligeiramente achatada dorsoventralmente, $10 \times 7 \mathrm{~mm}$. O número de segmientos é 328. No animal clitelado o diâmetro anterior é de $11 \mathrm{~mm}$, no clitelo e na região mediana $10 \mathrm{~mm}$. Os dois primeiros segmentos são rudimentares e encontram-se invaginados em todos os exemplares, juntamente com o prostômio, que é tentaculiforme. Os segmentos III - VIII, X são unianelares, os demais bianelares. A cor do dorso é marrom avermeThada, semelhante à do N. 109 de Séguy (1936); o ventre é marrom claro, como a . $^{\circ}$ 233 e o clitelo violeta escuro como o n. 628.

O clitelo não está intumescido, mas evidericia-se pela marcante diferença de cor. É em forma de sela, sem limite inferior bem definido, nos segmentos XVII - XXV $(=9)$. Um par de sulcos longitudinais percorre os segmentos $X X-X X I I$, lateralmente às cerdas $b$, deixando entre si uma área retangular ligeiramente aprofundada (Fig. 33). Nesta área os sulcos intersegmentares $20 / 21-22 / 23$ são mais profundos e formam largas reentrâncias em série com as cerdas $b$. Papilas circulares ou ovaladias e pequenas envolvem as cerdas ventrais e laterais dos segmentos VII e VIII e as ventrais de XVIII, XIX - XXIII. Os poros genitais sãc microscópicos. Os masculinos são em número de 2 pares. Os dois poros de cada lado situam-se um ao lado do outro, no terço anterior do segmento XX, nos sulcos longitudinais, $\mathrm{O}$ par de poros femininos abrem:se na região posterior de XVII, em série com as cerdas $b$. Três pares de poros de espermatecas abrem-se em $6 / 7-8 / 9$, em linha com os nefridióporos, que são reconhecíveis a partir de $4 / 5$, em série com $c d$.

As cerdas têm distribuiçăo lumbricina regular a partir do segmento VI. As cerdas normais têm a forma de um S alongado, com pequeno espessamento submediano. O quarto apicall é ornamentado por 4 séries alternas de cicatrizes semilunares, largas e transversais (Fig. 34). O número de cicatrizes por série varia de $4-6$, sendo mais freqüente $5-6$ nas cerdas ventrais e $4-5$ nas laterais. $\mathrm{Na}$ região mediana do corpo o comprimento cias cerdas ventrais é $1,283 \mathrm{~mm}$ e das iaterais 0,957 $\mathrm{mm}$ em média. As cerdas ventrais e laterais dos segmentos VII e VIII e as ventrais de XVIIi, XIX - XXII, XXIII transformam-se em genitais. Fstas cerdas săo quase retas e com os $2 / 3$ $3 / 4$ apicais ornamentados por 4 séries de cicatrizes com a forma de escavaçōes profundas $e$ abertas para o ápice. As escavaçōes ao longo de cada cerda podem dispor-se segundo uma hélice (Fig. 35) ou alternas duas a duas (Fig. 36). Em uma única cerda pode-se encontrar um padrão na base e outro no ápice. Nos segmentos VII e VIII, o número de cicatrizes varia de $12-14$ nas cerdas ventrais e de $16-17$ nas laterais. Nos segmentos XVIII, XIX XXII, XXIII este número varia de $18-23$, sendo mais freqüente 22. Em VII e VIII as cerdas laterais atingem em média $2,815 \mathrm{~mm}$ de comprimento por 68,75 um de diâmetro basal; as cerdas ventrais tem o mesmo diâmetro, mas são mais curtas, o comprimenta médio é de $1,865 \mathrm{~mm}$. No clitelo as cerdas genitais são mais longas, seu comprimento é de $4,200 \mathrm{~mm}$ e o diâmetro basal 70,88 um em média. Nos segmentos $\mathrm{XL}-\mathrm{L}$, as relações entre as cerdas em dois animais sāo $a a: a b: b c: c d: d d$ $=5,55: 1,00: 11,36: 0,73: 22,00=6,00:$ $1,00: 9,83: 0,50: 22,50$.

Os septos $6 / 7-17 / 18$ são espessos, musculosos e com a forma de cones interpenetrados, que se tornam mais curtos para trás. Os demais septos são frágeis e transversais. Uma moela volumosa, cilindrica e musculosa situa-se na cavidade do segmento VI, porém dado seu desenvolvimento e do esôfago anterior, associados à forma cônica dos septos, ocupa o espaço correspondente aos segmentos $\mathrm{IX}$ - XI externos. Três pares de glândulas calciferas grandes, piriformes e de estrutura tubular composta (Kompositenschlauchtasche) abrem-se lateralmente no esôfago, nos segmentos VII - IX. Em cada glândula, a volumosa porção ental, desprovida de apêndice, encosta-se à simétrica sob o esôfago. O esôfago posterior continua simples até o segmento XXIV; a transição esôfago - intestino situa-se na altura do septo 24/25. O intestino forma duas bolsas laterais em XXV 
e continua a alargar-se para trás, até o segmento XXVII, onde atinge o diâmetro normal posterior. Cecos intestinais faltam. O tiflosole aparece como uma lâmina dorsal, curva em $\mathrm{S}$, a partir do segmento XXVI. Em cada segmento há um par de holonefrídios. Os nefrídios de VI e anteriores enovelam-se dos lados do esôfago anterior. O vaso dorsal é único e pode ser seguido até a face posterior da moela, onde se divide em 3 ramos. Três pares de corações laterais comunicam o vaso dorsal com o ventral nos segmentos VII - IX; quatro pares de corações intestinais volumosos unem o vaso supra-esofágico com o ventral em X - XIII.

Dois pares de sacos testiculares encontram-se em X e XI. Os simétricos fundem-se entre si, circundando o esôfago e os corações intestinais. Dois pares de vesículas seminais ovaladas prendem-se à face posterior dos septos $10 / 11$ e $11 / 12$; as do primeiro par são envolvidas pelos sacos testiculares de XI. Os dutos seminais de cada lado correm no interior da musculatura longitudinal, logo abaixo do peritônio. No segmento XVIII começam a aprofundar-se gradativamente na parede do corpo, até a abertura no terço anterior de XX. Um par de ovários laminares situa-se em XIII. Três pares de espermatecas aproximadamente do mesmo tamanho encontram-se em VII - IX. Em cada espermateca o duto é delgado e emite esporadicamente pequenas câmaras arredondadas. Em sua porção ental, o duto comunicase com numerosas câmaras maiores e ramificadas. Espermatozóides preenchem as câmaras e faltam no duto. O epitélio de revestimento do duto é chato e o das câmaras cilindrico, com núcleo basal. Toda a espermateca é envolvida por uma massa conjuntiva rica em núcleos, que se coram intensamente pela hematoxilina. Esta massa conjuntiva dispõemse em uma porção basal maior, presa ventralmente à parede do corpo e em uma porção distal menor, livre. O duto da espermateca corre na região anterior e dorsal da porção basal conjuntiva $e$ as câmaras terminais ficam na porção distal. Ampola diferenciada falta (Fig. 37).

\section{CONSIDERAÇÕmS}

Rhinodrilus lucilleae, sp. n. e R. mortis Righi, 1972, descrita de Mato Grosso, São José da Serra, săo as duas únicas espécies do gênero conhecidas por apresentarem dois pares de poros masculinos. As duas espécies distinguem-se pelos seguintes caracteres: $R$. lucilleae - poros masculinos em XX (F. mortis - em XXII) ; espermatecas sem ampola definida (com ampola).

O nome da nova espécie foi dado em homenagem à Srta. Lucille Marilyn May Krieger D'Amorim Antony pelo seu inextimavel auxílio em nossas coletas.

\section{Rhinodrilus curiosus, $\mathrm{sp} . \mathrm{n}$.} (Figs. 38-42)

\section{MATERIAL}

BRASIL, Amazonas: Estrada Manaus-Itacoatiara, Km 26 (Reserva Ducke), em solo arenoso próxlmo ao igarapé do Barro Branco, 1 exemplar clitelado e 4 maduros aclitelados (INPAZ-38), I. Ayres e E. F. Nascimento col, 25/8/1975.

No animal clitelado o comprimento é de $155 \mathrm{~mm}$ e o diâmetro na região anterior 4,1 $\mathrm{mm}$, no clitelo $5,7 \mathrm{~mm}$, na região mediana do corpo $4,4 \mathrm{~mm}$ e na região posterior, que é achatada dorso-ventralmente, mede $4,1 \times 2,7 \mathrm{~mm}$. o número de segmentos é 192. Os dois primeiros segmentos são rudimentares, percorridos por um sulco longitudinal de cada lado, na linha dos nefridióporos e estão invaginados na maioria dos animais. A cor do dorso é marrom, semelhante ao n. 115 de Séguy (1936), pouco mais escura no clitelo e o ventre é cinza claro semelhante ao $\mathrm{n} .^{\circ}$ 535. O prostômio tentaculiforme está invaginado em todos os exemplares e seu músculo retrator prende-se na parede dorsal e anterior do segmento V. O clitelo é em forma de sela nos segmentos $1 / 2$ $X V I-X X V(=9,5)$. Em todos os exemplares, a porçâa mediana e ventral do segmento $X X I$ é bastante aprofundada e limitada lateralmente por dois espessamentos. Estes espessamentos são também deprimidos em relaçāo ao restante da superfície do segmento, da qual se separam por um sulco convexo. No animal clitelado, a depressão mediana e os espessamentos laterais são divididos ao meio por um sulco transversal. Os limites anteriores e posteriores da depressão são feitos por duas projeções posteriores do segmento $X X$ e outras duas anteriores em XXII. Estas projeçōes po- 
dem ser mais ou menos separadas por um entalhe mediano e longitudinal (Figs. $39-40$ ). Dois pares de papilas de contorno mal definido e de cor esbranquiçada situam-se em XVIII e XIX. No ápice destas papilas localizam-se as cerdas ventrais. Nos cortes vê-se que nestas papilas abrem-se tufos de células glandulares, que estão aprofundadas na musculatura circular. Estruturas glandulares semelhantes, localizadas no interior da musculatura circular, encontram-se nos segmentos $\mathrm{VII}-\mathrm{X}$ e XX $X X I I$, sem formarem saliencias na superfície. No segmento XVII do animal clitelado há uma depressão transversal e ventral, cujos bordos espessos têm o aspecto aproximado de um ovóide; nas extremidades da depressão situam. se as cerdas ventrais. Outras depressões mediana, ventral, de bordos laterais bem definidos e ligeiramente divergentes para trás, encontram-se no segmento $X X$.

As cerdas ventrais são reconheciveis a partir do segmento VII e as laterais entre X XIII. As cerdas comuns são sigmóides, alongadas e com pequeno espessamento submediano (Fig. 38). O quinto apical é ornamentado por 4 séries de cicatrizes geralmente alternas entre si, mas em algumas cerdas duas séries adjacentes estão na mesma altura, alternando-se com as outras duas. O número de cicatrizes por série varia de $4-8$, em geral 4 ou 5. O comprimento das cerdas torna-se ligeiramente maior nos sentidos dorso-ventral e antero-posterior. Em 10 medidas na região mediana do corpo, o comprimento médio das cerdas é $c, d=441,25 \mu \mathrm{m}$ e $a, b=495,00 \mu \mathrm{m}$ e na região posterior $c, d=516.25 \mu \mathrm{m}$ e $a, b=$ $593,75 \mu \mathrm{m}$. No anima! clitelado a relação entre as cerdas na região mediana do corpo (segmentos $L X X-L X X X)$ é $a a: a b: b c: c d: d d=7,4$ : $1,: 10,8: 0,7: 24,0$ e na região posterior (segmentos CLXX - CLXXX) é aa : ab : bc : cd : dd $=5,6: 1,0: 5,0: 0,9: 14,0$. As cerdas ventrais dos segmentos VII - IX e XVIII - XXII transformam-se em genitais. As de VII - IX localizam-se próximas aos poros das espermatecas, sendo as de VII e VIII nas vizinhanças do primeiro par de poros e as de IX do segundo par. As cerdas genitais são retas em sua maior porção", com ligeira curvatura ental (Fig. 41); raramente são um pouco arqueadas. Sua metade apical é ornamentada por 4 séries alternas de cicatrizes profundas, que lhes dá um aspecto ondulado. $\mathrm{O}$ número de cicatrizes por série varia de $13-17$ e este número não está relacionado com o comprimento das cerdas. A variação nas medidas das cerdas genitais cias duas regiões é semelhante, oscilando entre $1,0-1,3 \mathrm{~mm}$ de comprimento por $25-35 \mu \mathrm{m}$ de diâmetro basal, sendo ligeiramente maiores as de XX.

Os septos anteriores são cônicos e alongados para trás, tornando-se sucessivamente mais curtos até o 15/16; os demais septos são mais ou menos transversais. Os septos $6 / 7$ $8 / 9$ são espessos e musculosos. As porçỏes ventro-laterais dos $20 / 21$ e $21 / 22$ são especialmente musculosas e provavelmente é a sua contração que provoca o aprofundamento da superfície ventral do segmento XXI. Os demais septos são frágeis. Os septos $6 / 7$ $8 / 9$ prendem-se aos intersegmentos correspondentes. O septo $9 / 10$ prende-se ao intersegmento $10 / 11$, o $10 / 11$ ao $11 / 12$ e assim sucessivamente até 0 intersegmento $16 / 17$. O septo $16 / 17$ parte da região mediána do segmento XVII e o $17 / 18$ do próprio intersegmento. Daqui para trás a segmentação externa corresponde à interna. Deste modo, a cavidade do segmento IX corresponde externamente aos segmentos IX e X, a cavidade de X corresponde ao XI externo e assim sucessivamente até a cavidade de XV. Devido à forma e fragilidade de alguns septos, suas relações parietais. descritas acima, só puderam ser elucidadas em cortes seriados, que ainda foram prejudicados pela presença de terra no trato digestivo. Antes de compreendermos a septação tivemos muita dificuldade, porque as gônadas situamse, pela segmentação parietal, um segmento para trás do esperado.

Uma moela piriforme e musculosa situa-se em VI. Três pares de glândulas calcíferas !ocalizam-se em VII - IX. Estas glândulas são aproximadamente do mesmo tamanho e piriformes, abrindo-se dorso-lateralmente no esôfago através de curto duto; sua estrutura é do tipo tubular composto (Kompositenschlauchtasche). O intestino começa a dilatar-se no segmento XXIV, atingindo o diâmetro normal, posterior em XXVI. Cecos intestinais faltam. $\mathrm{O}$ tiflosole inicia-se em XXV e tem a forma de uma lâmina dorsal, larga e curva em S. Em 
cada cavidade segmentar há um par de holonefrídios, que se abre na superfície em série com cd. Os nefrídios de $\mathrm{VI}$ e anteriores formam um enovelado de cada lado do esôfago anterior. 0 vaso dorsal é simples e pode ser seguido até o segmento VII. Três pares de corações laterais localizam-se em VII - IX e dois pares de corações intestinais em X e XI.

Dois pares de volumosos sacos testiculares encontram-se em X e XI, envolvendo os corações intestinais. Os do primeiro par fundem-se também dorsalmente, originando um anel ao redor do esôfago. Dois pares de vesiculas seminais largas e de bordo livre crenulado situam-se em XI e XII. Um par de glândulas prostáticas sésseis, volumosas, frágeis e de cor branca leitosa desenvolvem-se de cada lado do esôfago no segmento $\mathrm{XX}$, distendendo o septo $19 / 20$ para diante. Nos cortes verifica-se que cada próstata é percorrida por um duto axial volumoso, constituido por células altas, cilíndricas e com revestimento cuticular. Em pontos esparsos o duto forma curtos divertículos. A massa principal da próstata é formada por células glandulares granuiosas em forma de maçã, com a parte mais volumosa na periferia e o longo pescoço abrindo-se no duto central. Delgados tabiques conjuntivos isolam grupos de células glandulares; fibras musculares faltam. Algumas células glandulares de cada próstata atravessam a porção ventro-lateral do septo $20 / 21$, elevando-se como um pequeno par de divertículos em XXI. Envolvendo as próstatas encontra-se o delicado peritònio, constituído por células pavimentosas. Os dois pares de dutos seminais de cada lado correm juntos sobre a porção ventro-lateral da parede do corpo. No segmento XX elevam-se pela face medial da próstata, abrindo-se na porção ental do duto prostático. A porção intra-parietal do par de dutos prostáticos é envolvida por uma capa muscular e abre-se na superfície no intersegmento $20 / 21$, em série com as cerdas b. Um par de ovários laminares prende-se ventro-lateralmente na face posterior do septo $12 / 13$. Os dois ovidutos volumosos atingem a superfície no terço posterior do segmento $\mathrm{XVII}$, em série $\operatorname{com} b$. Os poros femininos ainda não estão "abertos nos animais estudados. Dois pares de espermatecas encontram-se em VIII e IX. Sua organização é semelhante, po- rém as de IX são quase duas vezes maiores do que as de VIII. As espermatecas são piriformes e não há separação nítida entre duto e empola (Fig. 42). Da região do duto junto à parede do corpo parte um pequeno divertículo arredondado e anterior, no interior do qual encontram-se algumas câmaras seminais. Raras câmaras seminais partem do duto no lado oposto ao divertículo. As paredes internas do duto, das câmaras seminais e a da região basal da ampola apresentam numerosas dobras. O i: terior da ampola está preenchido por uma massa albuminóide onde se encontram nume. rosos Nematoda. Espermatozóides acumulam. se no duto e nas câmaras seminais. Os dois pares de poros das espermatecas situam-se próximo à linha média ventral, em $7 / 8$ e $8 / 9$.

\section{CONSIDERAÇÕES}

Rhinodrilus curtos Stephenson, 1931, conhecido apenas pela descrição original de um animal aclitelado proveniente de Trinidad, Monte Tucouché, é a única espécie do gênero dotada de próstata. Desvios na organização do aparelho reprodutor masculino não são raros entre as espécies de Rhinodrilus. R. contortus Cernosvitov, 1938 e R. priollii Righi, 1967 apresentam um par de câmaras copulatórias e $R$. mortis Righi, 1972 e R. lucilleae Righi, Ayres e Bittencourt apresentam dois pares de poros masculinos.

$R$. curiosus, sp. n. distingue-se de $R$ cur. tus pelos seguintes caracteres: $R$. curiosus na região mediana do corpo aa $=7 a b(R$. curtus - $a a=4 a b$ ); falta septo no intersegmento $9 / 10$ (falta no $8 / 9$ ); próstata em XX (em XXI); poros das espermatecas em $7 / 8$ e $8 / 9$ (em $6 / 7$ e $7 / 8$ ); duto da espermateca com um pequeno divertículo (sem divertículo).

\section{Rhinodrilus elisianae, $\mathrm{sp} . \mathrm{n}$.} (Figs. 43-45)

\section{MATERIAL}

BRASIL, Amazonas: Sucunduri (Estrada Transamazônica, trecho Humaitá-Jacareacanga, $\mathrm{Km}$ 523) em barranco de solo arenoso, na margem de um igarapé, 3 exemplares clitelados e 2 maduros aclitelados (todos sem a extremidade posterior) (INPAZ-47), E. Rufino, L. Antony e G. Righi col. 28/6/1975. 
O maior dos exemplares fragmentados está clitelado. Seu comprimento é de $210 \mathrm{~mm}$ e o diâmetro na região anterior $4,15 \mathrm{~mm}$, no clitelo $4,77 \mathrm{~mm}$, na região mediana do corpo $3,0 \mathrm{~mm}$ e na porção mais posterior $2,6 \mathrm{~mm}$. O número de segmentos é 436 . O prostômio está invaginado em todos os exemplares. O primeiro segmento tem a parede membranosa, o segundo é sulcado longitudinalmente em toda a superfície. Os demais segmentos são ligeiramente trianelares. A cor geral do corpo é branca e o clitelo alaranjado como o $\mathrm{n} .^{\circ} 190 \mathrm{de}$ Séguy (1936) .

$O$ clitelo, bastante entumescido, é em forma de sela nos segmentos XV $-\mathrm{XXV}(=11)$. Um par de traves pubertais largas e planas estende-se de $X X-1 / 2 X X I I$; sua margem iateral é saliente e de aspecto crenulado, a margem medial é mal definida. A face ventral dos segmentos XVI - XXIII, XXIV é reentrante como uma canaleta. Em cada segmento de $\mathrm{XVI}$ - XXV há um sulco transversal mediano $\mathrm{e}$ ventral, mais profundo em XIX - XXIII. Papilas pubertais ovaladas, pouco elevadas e crateriformes envolvem as cerdas ventrais de XIXXXIII. Estas papilas situam-se no interior de uma área glandular de cor branca leitosa e contorno mais ou menos retangular (Fig. 45). Nos enimais clitelados a face ventral dos segmentos VII - XIII apresenta-se espessada, mas sem diferenciação de papilas pubertais. Os poros genitais são microscópicos. O par de poros masculinos abre-se no intersegmento $20 / 21$, no interior das traves pubertais. Os poros femininos situam-se em $14 / 15$, ligeiramente medianos à linha de cerdas a. Dois pares de poros de espermatecas encontram-se em $7 / 8$ e $8 / 9$, em série com $c d$.

As cerdas são em número de 4 pares đíspostos regularmente ao longo do corpo, a partir do segmento II. As cerdas comuns são sigmóides, com ligeiro espessamento submediano e com o quarto apical ornamentado por 4 séries de cicatrizes alternas. Em cada série encontram-se 2 cicatrizes profundas, em forma de largas meia-luas. Nos segmentos $\mathrm{XL}-\mathrm{L}$, - comprimento médio das cerdas ventrais é $222 \mu \mathrm{m}$ e das laterais $210 \mu \mathrm{m}$. Nesta regiâo a relaçăo entre as cerdas, em dois animais, é a seguinte $a a: a b: b c: c d: d d=14,6: 1,0$ : $10,0: 0,8: 32,6=17,0: 1,0: 13,7: 1,0: 43,0$.
As cerdas ventrais dos segmentos XVI XXIII transformam-se em genitais. Estes cerdas são retas em sua maior porção, com pequeno espessamento submediano e ligeira curvatura ental. Em um animal o comprimento destas cerdas varia de $587-650 \mu \mathrm{m}$. em média $630 \mu \mathrm{m}$ e a espessura, no terço basal, varía de $20-30 \mu \mathrm{m}$, em média $25 \mu \mathrm{m}$. Em outro exemplar, o comprimento varia de $562-600 \mu \mathrm{m}$, em média $579 \mu \mathrm{m}$ e a espessura de $20-25 \mu \mathrm{m}$ em média $21 \mu \mathrm{m}$. O terço apical das cerdas genitais é ornamentado por 4 séries de cicatrizes semilunares abertas para o ápice e dispostas alternadamente (Fig. 43). O número de cicatrizes por série varia, no animal de cerdas mais longas, de $9-12$ e no de cerdas mais curtas de $5-9$.

Os septos $6 / 7-9 / 10$ são espessos, musculosos e com a forma de cones interpenetradios. Os demais septos são frágeis e mais ou menos transversais. A posição do septo $6 / 7$ é normal, prendendo-se no intersegmento correspondente. $\mathrm{O}$ 7/8 tem inserção normal em um exemplar, mas em outros dois prendese ventralmente no no intersegmento $7 / 8 \mathrm{e}$ dorsalmente no $8 / 9$. Nos 3 animais estudados, os septos $8 / 9$ e $9 / 10$ prendem-se ventralmente no intersegmento correspondente e dorsalmente nos $9 / 10$ e $10 / 11$ respectivamente. Uma moela globóide e fortemente muscular encontra-se em VI. Três pares de glândulas calcíferas tem seus dutos delgados abrindo-se ventralmente no esôfago, nos segmentos VII - IX. As glândulas são aproximadamente do mesmo tamanho e piriformes. Uma forte constriçáo separa um pequeno apêndice arredondado, ter. minal. A estrutura destas glândulas é do tipo tubular - composto (Kompositenschlauchtasche) . O intestino inicia-se em XVIII ou XIX e, a partir do segmento XXVII, apresenta um tiflosole com a forma de uma lâmina dorsal, larga e curva em S. Cecos intestinais faltam. Dois pares de corações intestinais volumosos situam-se em $\mathrm{X}$ e $\mathrm{XI}$ e três pares de corações laterais em VII - IX. Em cada segmento há um par de holonefrídios abrindo-se através de forte esfincter, em série com as cerdas laterais.

Dois pares de volumosos sacos testiculares fundem-se entre si nos segmentos $\mathrm{X}$ e XI, envolvendo o esôfago e coraçōes. As vesícu- 
las seminais são longas, estendendo-se sobre e dos lados do intestino até o segmento XXX. Um par de ovários laminares situam-se ventralmente em XIII. Dois pares de espermatecas encontram-se em VIII e IX. As espermatecas dos dois pares podem ser do mesmo tamanho ou as do segundo par pouco maiores. Em cada espermateca, a ampola é ovóide e chatada e o duto delgado e tão longo quanto o maior comprimento da ampola (Fig. 44). Câmaras seminais faltam.

\section{CONSIDERAÇÕES}

Por apresentar dois pares de espermatecas, Knınodrilus elisianae, sp. n. alia-se ao grupo de espécies formado por $R$. paradoxus $E$. Ferrier, 1872, R. appuni (Michaelsen, 1892), $R$. sieversi (Michaeisen, 1895), R. romani Michaeisen, 1928, R. curtus Stephenson, 1931, R. gitus Righi, 1971 e R. curiosus Righi, Ayres e bittencourt. Estas espécies são conhecidas apenas do norte da América do Sul e podem ser separadas pelá chave abaixo.

O nome da nova espécie foi dado em ho. menagem à Sra. Elisiana Oliveira-Rufino, que tanto nos auxiliou nas coletas.

Chave para as espécies de Rhinodrilus E. Perrier, $1872 \mathrm{com}$ dois pares de espermatecas.

1 - Um par de próstatas no segmento $\mathrm{XX}$ e ou

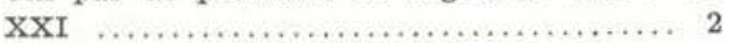

— Próstatas ausentes .................... 3

2 - Poros das espermatecas em $6 / 7$ e $7 / 8$ R. curtus

— Poros das espermatecas em $7 / 8 \mathrm{e}$ $8 / 9 \ldots \ldots \ldots \ldots \ldots \ldots \ldots \ldots \ldots \ldots \ldots \ldots \ldots$ R. curiosus

3 - Animais pequenos, com menos de $3 \mathrm{~cm}$ comprimento. Poros das espermate-

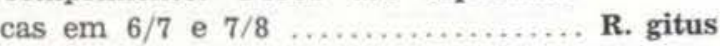

- Animais de porte médio ou grande, com mais de $8 \mathrm{~cm}$ de comprimento. Poros das espermatecas em $7 / 8$ e $8 / 9 \ldots \ldots \ldots \ldots .4$

4 - Traves pubertais presentes ............. 5

- Traves pubertais ausentes .............. 6

5 - Espermatecas com câmaras seminais. Um par de cecos intestinais. Todos os septos frágeis ... R. paradoxus

- Câmaras seminais e cecos intes. tinais ausentes. Septos $6 / 7-$ $9 / 10$ espessos ................ R. elisianae

6 - Septos anteriores $(6 / 7-12 / 13,13 / 14)$ espessos, os demais frágeis .............. 7

— Todos os septos frágeis ........ R. romani
7 - Cerdas ventrais das regiōes mediana e posterior do corpo fortemente geminadas ( $a \mathbf{a}= \pm 12 \mathbf{a b}) \ldots \ldots \ldots \mathbf{R}$. appuni

- Cerdas ventrais das mesmas regiōes largamente separadas $(a \mathbf{a}=2 \mathrm{ab}) \quad \ldots \ldots \ldots \ldots \ldots \ldots, \mathbf{R}$. sieversi

Amazo, gen. $\mathrm{n}$.

\section{DIAGNOSE}

Cerdas dispostas em 8 linhas longitudinais regulares. Um par de poros masculinos intraclitelares. Moela no segmento VI. Glândulas calcíferas como simpes dilatações esofágicas em XV e XVI, de estrutura trabecular (Leistentosche). Metândrico e metagínico. Vesículas seminais restritas a um segmento. Espermatecas presentes, post-testiculares.

Tipo do gênero: Amazo nia, sp. n.

\section{CONSIDERAÇÕES}

Pela estrutura trabecular das glândulas calciferas, Amazo aproxima-se do grupo constituído por Diachaeta Benham, 1887, Anteoides Cognetti, 1902 e Periscolex Cognetti, 1905, tomados no sentido de Michaelsen (1918), bem como de Cirodrilus Righi, 1975. Nos quatro gêneros citados as glândulas são bem separadas do esôfago e não simples dilatações da parede esofágica, como em Amazo. O novo gênero distingue-se também pela posição das glândulas calciferas, que em Diachaeta localizam-se nos segmentos VII - IX, Anteoides em VII - X, Periscolex em VII e Cirodrilus em VIII e IX. Amazo distingue-se ainda por apresentar espermatecas unicamente post-testiculares; nos gêneros acima são exclusivamente prétesticulares.

Glândulas calciferas como expansōes saculiformes, abertas largamente no esôfago ocorrem em Atatina Righi, 1971, que difere de Amazo pelas glândulas situarem-se nos seg. mentos IX - XIII e serem estruturadas por lamelas irregulares.

\section{Amazo nia, sp. $n$.}

(Figs. 46-51)

\section{MATERIAL}

BRASIL, Amazonas: Sucunduri, próximo à confluência da Estrada Transamazônica com o rio Su- 
cunduri, em solo arenoso e no interior de troncos podres periodicamente submersos da margem do igarapé da Caixa d’Água, 6 exemplares clitelados (4 sem a extremidade posterior), 14 maduros aclitelados e 2 jovens (INPAZ-50), L. Antony, E. Rufino, E. Froehlich e G. Righi col. 26/6/1975.

O comprimento dos animais varia de 36 -. $40 \mathrm{~mm}$. O diâmetro pré-clitelar varia de 1,5 $1,6 \mathrm{~mm}$, no clitelo de $1,6-1,7 \mathrm{~mm}$, na região mediana do corpo de 1,2 - 1,6 mm e na posterior de 1,0-1,2 mm. Os últimos $\varepsilon-10$ segmentos afilam bruscamente, terminando no diminuto pigídio, que se prolonga, ventralmente ao ânus, por um pequeno apêndice digitiforme, maciço (Fig. 46). O número de segmentos é variável entre 122 - 130. A superfície do primeiro segmento é totalmente percorrida por numerosos sulcos longitudinais; os demais segmentos têm a superfície lisa. Em alguns exemplares, os segmentos pré-clitelares são ligeiramente bi ou tri-anelares. O prostômio tentaculiforme está invaginado em todos os animais. Pigmento falta.

As cerdas apresentam distribuição lumbricina regular a partir do segmento III. O espaço aa diminui do segmento XII $-X V$, é igual em $X V$ e XVI, aumenta gradativamente até o segmento $X X$ ou $X X I$, continuando mais ou menos uniforme para trás. As relações entre as cerdas em 4 animais encontram-se na Tabela 5. As cerdas são em forma de $\mathrm{S}$, com um nódulo no início do terço distal e a extremidadહ apical bicuspidada (Fig. 48). O cúspide proximal é maior e tem uma face lisa e a outra espessa e rugosa (Fig. 47). Na região mediana do corpo o comprimento das cerdas varia de 175 $216 \mu \mathrm{m}$, em média $187 \mu \mathrm{m}$.
O clitelo é em forma de sela nos segmentos XIV - XX (=7). Seu limite inferior e bem perceptivel em $1 / 2$ bc nos segmeniss $X V I I-X X$. A área ventral de $X V-X V I I$ apresenta-se ligeiramente espessada. Um par de traves pubertais volumosas salienta-se na metade ventral de $b c$, nos segmentos $X V-X V I$ (Fig. 49). Cada trave é percorrida medianamente por um sulco profundo, em forma de colchete aberto lateralmente. O sulco horizontal posterior do colchete situa-se em 1/2 XVI e o anterior coincide com o intersegmento 15/16. No sulco horizontal anterior encontrase uma papila ovalada. O par de poros masculinos localiza-se no terço anterior de XVI, no interior dos sulcos longitudinais dos colchetes O par de traves pubertais diferencia-se antes do clitelo durante c processo de maturaçãu. Dois pares de papilas circulares, com a margem ligeiramente espessada, situam-se na região posterior dos segmentos XIII e XIV, pouco abaixo da linha de cerdas $c$. No centro destas papilas abrem-se os poros das espermatecas.

Os septos são todos frágeis. Os 6/7 9/10 têm a forma de cones interpenetrados, os demais são frágeis. Uma moela ovóide e fortemente muscular situa-se em VI, mas devido à forma dos septos, ocupa o espaço dos segmentos VIII - X externos. O esôfago posterior é dilatado em VII, continuando como um tubo delgado até o segmento XIV. Em XV e XVI dilata-se e tem cor branca leitosa, cunstituindo as glândulas calcíferas, que não são pedunculadas. Estas glândulas são compostas por numerosas trabéculas de alturas diferentes e, em geral, livres no centro das glândulas, mas podem fundir-se em alguns pontos (Fig.

TABELA 5 - Amazo nia, gen. n., sp. n., relaçōes entre as cerdas de 4 exemplares. Os exemplares A e B são maduros aclitelados e os C e D clitelados.

\begin{tabular}{|c|c|c|c|c|c|c|c|c|c|c|c|c|c|c|c|c|c|c|}
\hline \multirow{2}{*}{ Exemplar } & \multicolumn{9}{|c|}{ Segmentos XL $-\mathbf{L}$} & \multicolumn{9}{|c|}{ Segmentos $\mathrm{C}-\mathrm{CX}$} \\
\hline & aa & : & $\mathbf{a b}$ & : & bc & : & cd & : & dd & aa & : & $\mathbf{a b}$ & : & be & : & cd & : & dd \\
\hline A & 7,14 & : & 1,00 & : & 9,71 & : & 1,42 & : & 22,57 & 3,80 & : & 1,00 & : & 4,30 & : & 1,10 & : & 11,60 \\
\hline B & 7,35 & : & 1,00 & : & 8,85 & : & 1,07 & : & 19,42 & 3,41 & : & 1,00 & : & 4,70 & $:$ & 1,17 & : & 11,58 \\
\hline$=\mathrm{C}$ & 5,85 & : & 1,00 & : & 7,14 & : & 0,85 & : & 17,14 & 3,23 & : & 1,00 & : & 3,88 & : & 0,88 & : & 11,29 \\
\hline D & 6,25 & : & 1,00 & : & 7,25 & : & 1,00 & : & 15,75 & 3,78 & : & 1,00 & : & 3,68 & : & 0,94 & : & 10,73 \\
\hline Média & 6,64 & : & 1,00 & : & 8,23 & : & 1,08 & : & 18,72 & 3,55 & : & 1,00 & : & 4,14 & : & 1,02 & : & 11,30 \\
\hline
\end{tabular}



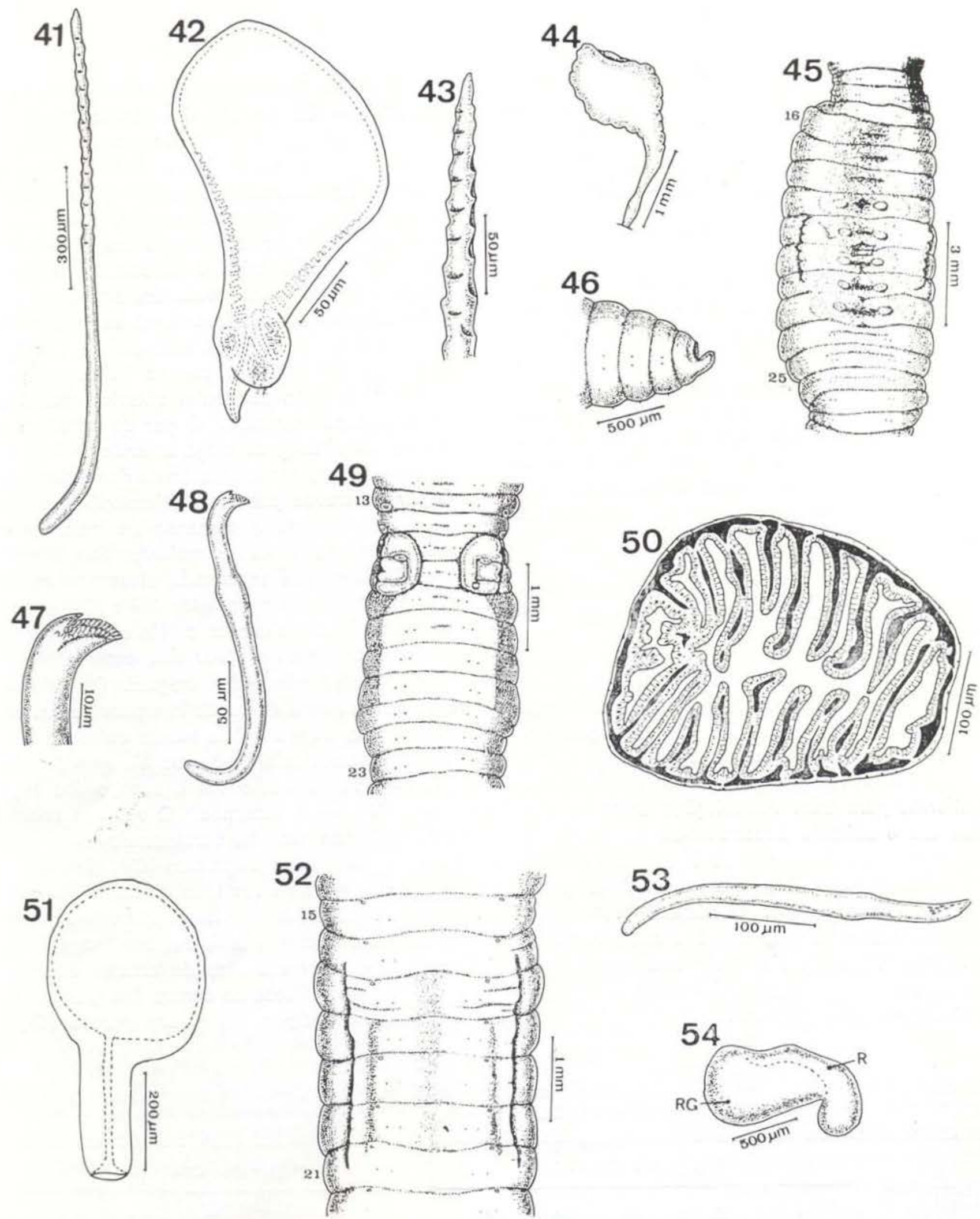

ESTAMPA V - Rhinodrilus curiosus, sp. n.: 41 - cerda genital do segmento XXI; 42 - espermateca de VIII. Rhinodrilus elisianae, sp. n.: 43 - ápice de cerda genital de XX; 44 - espermateca de IX; 45 - face ven tral de XIII - XXVIII. Amazo nia, gen. n., sp. n.: 46 - últimos segmentos e pigídio; 47 - ápice de cerda da região posterior; 48 - cerda da região posterior; 49 - face ventral de XIII - XXIII; $50-$ corte trans. versal de glândula calcífera de XVI; 51 - espermateca de XIV. Glossodrilus (G.) sucunduris, sp. n.: 52 - face ventral de XV - XXI; 53 - cerda ventral de XXI; 54 - glândula calcifera esquerda vista de perfil. $(\mathrm{R}=$ reservatório; $\mathrm{RG}=$ região glândular $)$. 
50). Em nenhum caso foi encontrado restos de calcário no interior das glândulas. A transição esôfago-intestino situa-se em $17 / 18$, em $X X \circ$ intestino atinge o diâmetro normal posterior. O tiflosole apresenta-se como uma lâmina dorsal, larga e perpendicular, a partir do segmento XVIII. Cecos intestinais faltam. Do aparelho circulatório ressalta o vaso dorsal volumoso e simples. Quatro pares de coraçōes intestinais situam-se nos segmentos $\mathrm{X}-\mathrm{XIII}$ e três pares de corações laterais em VII - IX. Vaso subneural falta.

Um par de testículos e de funis seminais aparecem livres na cavidade do segmento $X:$, que está preenchida por uma massa de esper. matozóides. Um par de vesículas seminais curtas e lobuladas encontra-se de cada lado do esôfago, em XII. Os canais deferentes correm livres na cavidade do corpo até o segmento XVI' onde penetram na musculatura parietal, que é espessa na região das traves pubertais. Numerosos tufos glandulares salientam-se de cada lado do esôfago nos segmentos XV .XVI, XVII, abrindo-se nas traves pubertais. Em XIII há um par de ovários laminares, com a mar. gem livre digitada e com uma fileira de ovos em diferenciação por dígito. Nos três animais cortados para microscopia, o funil ovular es. querdo é maior do que o direito, que termina em fundo cego. $O$ oviduto direito falta e o esquerdo abre-se no segmento XIV, imediatamente na frente da cerda $a$. Dois pares de espermatecas situam-se nos segmentos XIII e XIV, sendo as do segundo par cerca de duas vezes mais volumosas. Em cada espermateca (Fig. 51) a ampola apresenta-se ar:edondada, cheia de espermatozóides e bem separada do duto. O epitélio de revestimento da ampola é constituído por células pouco mais altas do que largas e com grande vacúolo mediano, onde se encontram espermatozóides em reabsorção. O duto é musculoso e seu comprimento, incluindo a porção parietal, é ligeiramente menor do que o diâmetro da ampola.

O nome do novo gênero e espécie é uina corruptela da palavra "Amazonia".

Pontoscolex corethrurus (Fr. Müller, 1857)

Principais citaçốes:

Lumbricus corethrurus Fr. Müller, 1857: 113 .

Urochaeta corethrura, E. Perrier, $1874: 379$.
Pontoscolex corethrurus, Michaelsen, 1900: 425; 1918: 234; 1927: 369; 1933: 120; Eisen, 1900: 87; Moreira, 1903: 133; Stephenson, 1923: 439; 1931: 84; Lüderwaldt, 1927: 549; Cernosvitov, 1934: 56; 1935: 28; Gates, 1942: 99; 1943: 92; 1954: 219; 1972: 54; Bahl, 1942: 1; Cordero, 1944a: 5; Vannuci, 1953: 287; Omodeo, 1955: 209; Righi, 1971: 40; 1972b: 225; Righi \& Bittencourt, 1972: 155 .

\section{MATERIAL}

BRASIL, Amazonas: Manaus (INPA), 6 exemplares (3 clitelados) (INPAZ-54), G. Righi col. $19 / 6 / 1975$. Estrada Manaus-Itacoatiara, $\mathrm{Km} \mathrm{10,6}$ exemplares clitelados (INPAZ-55), E. F. Nascimen. to col. 10/5/1975; $\mathrm{Km} 26$ (Reserva Ducke), próximo ao igarapé do Barro Branco, 34 exemplares (10 clitelados) (INPAZ-41), E. Rufino, E. Froehlich, L. Antony e G. Righi col, 23/6/1975; $\mathrm{Km} \mathrm{30}$, em solo de cultivo de cacau, 6 exemplares ( 5 clitelados) (INPAZ-14), I. Ayres col. 12/10/1974. Margem de igapó próximo ao rio Tarumā-mirim, 10 exemplares (2 clitelados) (INPAZ-51), E. Rufino, H. Schubart e G. Righi col, 2/7/1975. Lago Castanho, em mata de várzea, 54 exemplares (14 clitelados) (INPAZ49), I. Ayres col. 6/1975. Lago Calado, sob serinsueiras, 5 exemplares (2 clitelados) (INPAZ-52), M. Knoplacher col. 1975. Paraná da Eva, lago Tupaíma, em troncos, 2 exemplares clitelados (INPAZ-53), L. Antony col. 24/5/1975. Lábrea, próximo ao rio Purus, 6 exemplares clitelados (INPAZ-13), N. Vasconcelos col. 28/7/1974.

Espécie bem conhecida que habita solos predominantemente arenosos e de distribuição circumundial, especialmente entre os paralelos de $30^{\circ} \mathrm{N}$ e $30^{\circ} \mathrm{S}$.

Glossodrilus (G.) sucunduris, sp. n. (Figs. 52 - 54)

\section{MATERIAL}

BRASIL, Amazonas: Sucunduri, em solo arenoso na margem do rio Sucunduri, próximo à Estrada Transamazônica, 10 exemplares clitelados e 6 jovens (INPAZ-48), L. Antony col. 29/6/1975.

Os animais são esbranquiçados, falta pigmento. O comprimento varia de $45-63 \mathrm{~mm}$. $\mathrm{Na}$ região anterior o diâmetro varia de 1,8 -$2,4 \mathrm{~mm}$, no clitelo de $2,3-2,6 \mathrm{~mm}$, na região mediana do corpo de $1,9-2,2 \mathrm{~mm}$ e na regiăo posterior de $1,5-1,6 \mathrm{~mm}$. O número de segmentos varia de $87-137$. O prostômio tentaculiforme está invaginado em todos os exemplares. O comprimento do primeiro seg- 
mento equivale a $1 / 3$ do segundo; os demais segmentos, especialmente os pré-ciitelares, são elevados na linha equatorial, onde se inserem as cerdas.

$\mathrm{O}$ clitelo é em forma de sela bastante intumescida nos segmentos XVI $-X X I \quad(=6)$. Um par de sulcos longitudinais encontra-se em bc, de 1/2 XVI, 2/3 XVI - 2/3 XXI (Fig. 52). A. margem lateral destes sulcos coincide com o limite inferior do clitelo. A margem medial é espessa e elevada, mais nos segmentos XVIII $-2 / 3 X X I$, onde se encontram duas ligeiras depressões longitudinais, laterais às cerdas $b$. Nestes segmentos a área de inserção das cerdas ventrais é ligeiramente elevada. O espaço entre as depressōes e os sulcos longitudinais correspondem a traves pubertais, que se oiferenciam antes do clitelo no processo de maturação. Uma ou duas papilas pubertais segrnentares tem posição variável, na região ventrolateral de um a três segmentos, entre cs VIII XII. As papilas são ovóides ou circulares, ligeiramente circunvaladas e com pequeria depressão mediana. Os poros genitais são microscópicos.

As cerdas dispõem-se em 4 pares de sèries longitudinais, regulares, a partir do segmento II. São sigmóides, com ligeiro espessamento submediano e com a porção côncava, apical, ornamentada por pequenas cicatrizes triangulares, dispostas irregularmente. As cerdas do clitelo tem a mesma forma (Fig. 53) porém são ligeiramente maiores. O comprimento médio das cerdas ventrais posteriores é de $294 \mu$ e das do clitelo $345 \mu$. As relaçốes entre as cerdas em 4 animais encontra-se na Tabela 6.
Os septos 6/7 - 10/11 tem a forma de cones interpenetrados. Os $7 / 8-10 / 11$ são espessos e musculosos, o $6 / 7$ pouco menos. Os demais septos são frágeis e mais ou menos transversais. Uma moela globóide e fortemente muscular situa-se em VI. Um par de glândulas calciferas localiza-se látero-dorsalmente ao esôfagc nos segmentos XI - XII. Cada glândula compõem-se de uma porção secretora piriforme (Fig. 54, RG), de estrutura tubular composta e de um reservatório membranoso, dorsal $(R)$, onde abrem-se os tubos glandulares. O reservatório termina, além da porção secretora, em forma de um saco curvo. A porção anterior e medial do reservatório prolonga-se como um pequeno duto, que se funde com o simétrico, na linha média dorsal do esôfago, onde se abrem em comum. O intestino inicia-se no segmento $X V$, já com o tiflosole. que é uma lâmina larga, espessa e constrita nos intersegmentos. Cecos intestinais faltam. Três pares de corações laterais delgados en. contram-se nos segmentos VII - IX e dois pares de corações intestinais em $\mathrm{X}$ e $\mathrm{XI}$, o úitimo par é o mais volumoso. Vaso subneural falta. Em cada segmento há um par de holonefrídios, que se abre na região anterior dos segmentos, pouco lateral à série de cerdas $b$.

Um par de sacos testiculares funde-se entre si ventralmente no segmento $\mathrm{XI}$, e eleva-se dos lados das glândulas calcíferas em XII. Um par de vesículas seminais em forma de fita constrita nos intersegmentos estende-se das lados do intestino, até o segmento $\mathrm{XL}-\mathrm{L}$. As vesículas são mais largas nos segmentos post-clitelares, onde suas margens são ligeiramente lobuladas. O duto seminal de cada lado

TABELA 6 - Glossodrilus (G.) sucunduris sp. n., relações entre as cerdas de 4 exemplares.

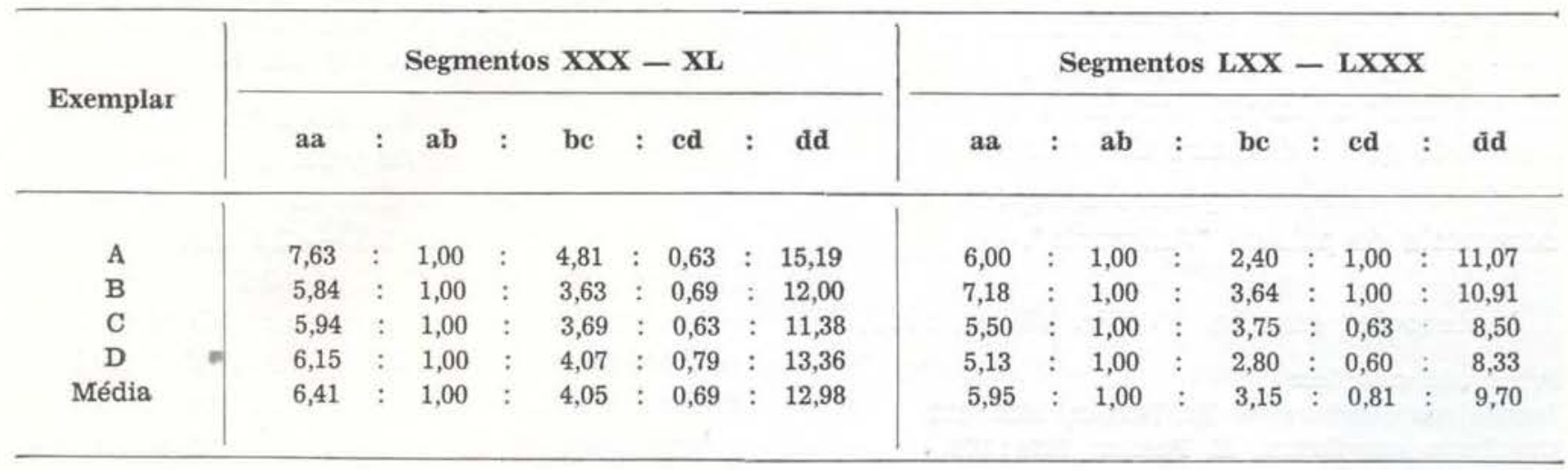


dirige-se inicialmente para diante, acompanhando a inclinação do septo $10 / 11$, e a seguir corre retilinearmente para trás, no interior da musculatura parietal longitudinal. $O$ par de poros masculinos situa-se no intersegmento $17 / 18$, em série com as cerdas $b$. Um par de ovários laminares, com a margem livre prolongada em dígitos com uma série de ovos em diferenciação, prende-se na face ventral e posterior do septo 12/13. Os ovidutos largos e curtos abrem-se na superfície no segmento XIV, imediatamente ao lado das cerdas a. As espermatecas são em número de 6 pares, sendo 2 pares em cada segmento de IX $-\mathrm{XI}$. Em cada espermateca a ampola saquiforme, volumosa e cheia de espermatozóides, separa-se nitidamente do duto que é delgado. De um modo geral, o comprimento do duto é tåo longo quanto o da ampola correspondente, mas pode ser mais curto, ou até 1,5 vezes mais longo. As espermatecas tornam-se maiores de diante para trás. Seus poros situam-se em 8/9 $10 / 11$, os das espermatecas ventrais em série com $a b$ e os das laterais com $c d$. O epitélio de revestimento das ampolas é cilíndrico, atingindo em média $19 \times 8 \mu \mathrm{m}$, com núcleo basal ovóide medindo em média $4,5 \times 3.5 \mu \mathrm{m}$. O plasma é de aspecto alveolar e, em cada célula, um ou dois alvéolos maiores contêm material anista corado em róseo claro, que também aparece sendo eliminado no ápice das células e livre na cavidade da ampola. No ápice das células encontram-se freqüentemente espermatozóides aderidos e sempre vários pedaços no interıo, do citoplasma. As células da região mais ectaı da ampola têm organização semelhante, alıando as funções secretora e fagocitária do excesso de espermatozóides recebidos do compánheiro. Contudo estas células ectais são geralmente mais altas, medindo em média $35 \times$ $8 \mu \mathrm{m}$ e o núcleo $5,5 \times 3,7 \mu \mathrm{m}$.

\section{CONSIDERAÇÕES}

Do gênero Glossodrilus Cognetti, 1905 são conhecidas 21 espécies distribuídas em dois subgêneros: Glossodrilus s. s. inclui 20 espécies (Righi, 1975: 86) que apresentam de $1-3$ pares de espermatecas e Tonperog Righi \& Ayres, 1975, monotípico, sem espermatecas.
G. (G.) sucunduris, sp. n. está bem caracterizado por apresentar 6 pares de espermatecas, sendo 2 pares em cada segmento de IX $X I$. Nas demais espécies do gênero, o maior número de espermatecas é de 3 pares, um em cada segmento de VII - IX ou VIII - X.

O nome da nova espécie deriva do nome do rio em cujas margens foi coletada.

\section{Agradectmentos}

Aos Drs. Warwick E. Kerr e Herbert O. R. Schubart, respectivamente Diretor e Chefe cio Laboratório de Pedobiologia do Instituto Nacional de Pesquisas da Amazônia, agradecemos as atenções e amplas facilidades com que nos distinguiram. Às biologistas do mesmo Instituto, Sra. Elisiana Oliveira-Rufino e Srta. Lucille M. M. K. A. Antony e ao técnico, Sr. Evaristo F. do Nascimento, somos gratos pela inestimável colaboração nos trabalhos de campo. A firma Camargo Corrêa S/A Construções e Comércio, agradecemos pelo transporte e utilização de suas instalações em Sucunduri.

\section{SUMMARY}

This paper deals with 13 species of Oligochaeta, Glossoscolecidae, from the Amazonian Brazil. Two new genera are erected, Tuiba, gen, $\mathrm{n}$. with two species, T. dianae, sp. n. and T. tipema, sp. n., and Amazo, gen. n. with one species, A. nia, sp. n. The following new species and subspecies are described. Andiorrhinus venezuelanus tarum:nis, subsp. n., A. caudatus, sp. n. Rhinodrilus brasiliensis buritis, subsp. n., R. lucilleae, sp. n. R. curiosus, sp. n., R. elisianae, sp. n., and Glossodrulus (ti.) sucunduris, sp. n. Andiorrhinus amazonius Michaelsen 1918 is redescribed. New occurrences are indicated for Andiodrilus icomi Righi, 1971, and for the pere grine earthworm Pontoseolex corethrurus (Fr. Müller, 1857), A key for the Rhinodrilus's species with two pairs of spermathecae is presented. Sperm resorption was seen in the spermathecae of Amazo nia and Glossodrilus (G.) sucunduris.

\section{BIBLIOGRAFIA CITADA}

BAHL, K. N.

1942 - Studies on the structure, development and physiology of Oligochaeta. III. The branching and division of nephri. dia and Eisen's so called "safety valves" in Pontoscolex. Quart. J. micr. Sc. $84: 1-17$. 
BENHAM, W. B.

1887 - Studies on earthworms, II. Quart. J. micr. Sc., n. s. $27: 77-108$, pls 8-9.

Cernosvitov, L.

1934 - Les oligochètes de la Guyane Française et d'autres pays de la Amérique du Sud. Bull. Mus. nat. Hist. Nat. (2) $6: 47-59$.

1935 - Oligochaeten aus dem tropischem Süd. -Amerika. Capita Zool, 6(1): 1-36, pls. 1-6.

1938 - Deux nouveaux Oligochètes Glossoscolecides du Brésil. Bull. Assoc. philom. Alsace et Lorraine, $1938: 401-497$.

COGNeTtI de MARTis, L.

1908 - Lombrichi di Costa Rica e del Venezue. la. Atti R. Accad. Sc. Torino, 43 : 505-518, pl. 1 .

Cordero, E. H.

1944a - Oligoquetos sudamericanos de la fami lia Glossoscolecidae, IV. Sobre algunas especies de Venezuela. Comun. Zool. Mus, Hist. Nat. Montevideo, 1(14) : 1-6.

1944b - Oligoquetos sudamericanos de la familia Glossoscolecidae, V. Eudevoscolex vogensangi, n. g., n. sp., de Venezuela, nueva forma com cierto número de caracteres primitivos. Comun. Zool. Mus. Hist. Nat. Montevideo, 1 (18) : $1-10, \mathrm{pl}, 1$.

EISEN, G.

1900 - Researches in the American Oligochaetz with special reference to those of the Pacific Coast and Adjavent Islands Proc. Calif. Acad. Sc. (3) $2: 85-276$ pls. 1-10.

GATES, G. E.

1942 - Check list and bibliography of North American earthworms. Amer Midl. Natur. 27: 86-108.

1943 - On some American and Oriental earti; worms. Ohio J. Sc. $43: 87.98$

1954 - Exotic earthworms of the United Staces. Bull. Mus. Comp. Zool. Harvard, 111 (6) : :219.258.

1972 - Burmese earthworms. Trans Amer. Philos. Soc. (N.S.) $62(7): 1326$.

LÜDERWALDT, $\mathrm{H}$.

1927 - A voleção de minhocas (Oligochaeta) no Museu Paulista. Rev. Mus. Paulista, 15 : 545-556.
Michaelsen, W

1892 - Terricolen der Berliner Zoologischen Sammlung. Arch. Naturg. 58 (1). 209-261, pl. 13.

1895 - Zur Kenntnis der Oligochäter. Abh. natur. Ver. Hamburg, $13: 1-37$, pl. 1.

1900 - Oligochaeta. Das Tierreich, 10 : XXIX $+575 \mathrm{pp}$. R. Friedländer und Sohn, Berlin.

1918 - Die Lumbriciden. Zool. Jahrb. Syst. 41: 1-398, pls. $1-2$.

1926 - Zur Kenntnis einheimischer and auslän. discher Oligochäten. Zool. Jahrb. Syst 51 : 255-328.

1927 - Die Oligochätenfauna Brasiliens. Abh. Senckenb. Naturf. Gesel. $40: 369-374$.

1928 - Miscellanea oligochaetologica. Ark. Zool 20 (2) : $1-15$

1933 - Die Oligochätenfauna Surinamcs. Tijds. Nederl. Dierk. Ver. (3) $3: 112-131$, pls $2-3$.

1935 - Oligochäten aus Peru. Capita Zool. 6 (2) : $1-12$

MOREIRA, C.

1903 - Vermes oligochetos do Brasil. Arch. Mus. Nac. Rio de Janeiro, $12: 125-136$.

MÜLLER, F.

1857 - Lumbricus corethrurus, Bürstensch. wanz. Arch. Naturg. 23 (1) : 113-116.

OMODEO, P.

1955 - Oligocheti terricoli del Venezuela rac. colti dal dr. Marcuzzi. Mem. Mus. civ Stor. Nat. Verona, 4:199-212.

PERRIER, E.

1872 - Recherches pour servir à l'histoire des Lombriciens terrestres. Nouv. Arch. Mus. Paris, $8: 5-198$, pls. $1-4$.

1874 - Etudes sur lorganization des Lombriciens terrestres. Arch. Zool. exp. gén. $3: 331-550$, pls. $12-17$.

RIGHI, G.

1967 - Descrição de Rhinodrilus priollii, sp. n. Glossoscolecidae da Amazônia, com bibliografia dos Oligochaeta Terricola de região. Atas Simpós. Biota Amazônica, $5: 475-479$.

1971 - Sôbre a familia Glossoscolecidae (Oli. gochaeta) no Brasil. Arq. Zool. S. Pau1o, 20 (1) : 1-96. 
1972a - Contribuição ao conhecimento dos Oligochaeta brasileiros. Papéis Avulsos Zool. S. Paulo, 25 (18) : 149-166.

$1972 \mathrm{~b}$ - On some earthworms from Central America. Stud. Neotrop. Fauna, 7: 207-228.

1974 - Notas sobre os Oligochaeta Glossoscolecidae do Brasil. Rev. Brasil. Biol. 34 (4) : 551-563.

1975 - Some Oligochaeta from the Brazilian Amazonia. Stud. Neotrop. Fauna, 10: 77-95.

RIGHI, G. \& I. AYres

1975 - Alguns Oligochaeta sul brasileiros. Rev. Brasil. Biol. 35 (2) : 309-316.

1976 - Meroscolex marcusi, sp. n. Oligochaeta, Glossoscolecidae da Amazônia. Bol. Zool. Univ. S. Paulo, 1:257-263.

Righi, G. \& E. C. R. BITTENCOURT

1972 - On the blood-system of Pontoscolex corethrurus (Fr. Müller, 1857) (Oligo- chaeta, Glossoscolecidae). Monitore Zool. Ital. (N.S.) $6: 155-178$.

SÉGUY, G

1936 - Code universal des couleurs. : $68 \mathrm{pp}$ 55 pls. Paul Lechevalier edit. Paris.

STEPHENSON, J.

1923 - Oligochaeta. Fauna of British India.: XXIV + $518 \mathrm{pp}$. Taylor \& Francis London.

1931 - Oligochaeta from Burma, Kenya and other parts of the World. Proc. Zool. Soc. Lond. 1931 : 33-92.

UDE, $\mathrm{H}$.

1894 - Beiträge zur Kenntnis ausländischer Regenwurmer. Zeits. wiss. Zool. 57: $57-75, \mathrm{pl} .4$.

VANNUCCI, M.

1953 - Biological notes, I. On the Glossoscolecidae earthworm Pontoscolex core. thrurus. Dusenia, 4 (4-5):287-300, pl 21. 